Article

\title{
Intrinsic and Spiritual Dimensions of Water at the Local Scale, and the Disconnect with International Institutions
}

\author{
Erica Lynn Porta ${ }^{1}$ and Aaron T. Wolf ${ }^{2, *(D)}$ \\ 1 Water Resources Graduate Program, Oregon State University, Corvallis, OR 97331, USA; \\ erica.lynn.porta@gmail.com \\ 2 College of Earth, Ocean, and Atmospheric Sciences, Oregon State University, Corvallis, OR 97331, USA \\ * Correspondence: Aaron.Wolf@oregonstate.edu
}

check for updates

Citation: Porta, E.L.; Wolf, A.T Intrinsic and Spiritual Dimensions of Water at the Local Scale, and the Disconnect with International Institutions. Sustainability 2021, 13, 8948. https://doi.org/10.3390/ su13168948

Academic Editor: Leslie A. Duram

Received: 1 July 2021

Accepted: 5 August 2021

Published: 10 August 2021

Publisher's Note: MDPI stays neutral with regard to jurisdictional claims in published maps and institutional affiliations.

Copyright: (c) 2021 by the authors. Licensee MDPI, Basel, Switzerland. This article is an open access article distributed under the terms and conditions of the Creative Commons Attribution (CC BY) license (https:/ / creativecommons.org/licenses/by/ $4.0 /)$.

\begin{abstract}
Local and indigenous populations the world over ascribe deeply and explicitly spiritual attributes to water. Springs, wells, and rivers are the homes of deities, have divine healing powers, and enhance processes of spiritual transformation. These attributes are rarely expressed in global declarations related to sustainable water management and are found only implicitly in a handful of international water treaties. This paper uses a multi-scalar lens to identify areas of disconnect between community-specific intrinsic and spiritual dimensions of water, regional management institutions or international agreements, and global conventions. The scale-based structure of the article highlights the systems-based connections, and disconnections, from global to local-scopes of dimensions of water enshrined in different institutions.
\end{abstract}

Keywords: international institutions; transboundary water resources; local values; spiritualities; sustainable water management

\section{Introduction \\ 1.1. Scales of International Freshwater Management Institutions}

Freshwater resources are unique within natural resources management practices because of the multiple layers of importance water holds for both human and non-human uses (Some material in this article draws heavily from: Porta, E.L. (2021). Cross-cultural and Sustainability Values in International Freshwater Management Institutions. Masters of Science, Oregon State University, Corvallis, OR, USA, 12 June 2021). Agriculture, transportation, construction, energy, recreation, certain religious practices, basic ecosystem functioning, all rely on the presence and accessibility of water for some part of each system. Social and cultural practices grounded in both place-based and cross-culturally common traditions further add layers of importance to water management and access. Local and indigenous populations the world over ascribe deeply and explicitly spiritual attributes to water. Springs, wells, and rivers are the homes of deities, have divine healing powers, and enhance processes of spiritual transformation.

The international community has developed several guiding documents and concepts in the management of these challenging resources, particularly in cases in which water crosses borders. Probably best known of the global declarations are the Dublin Principles of 1992, developed for the 1992 Rio Earth Summit, laying out basic concepts of water governance. Two general conventions regarding transboundary waters came also in the 1990s: The Convention on the Protection and Use of Transboundary Watercourses and International Lakes (Water Convention) was adopted in Helsinki in 1992 and entered into force in 1996, while the Convention on the Law of the Non-navigational Uses of International Watercourses was adopted by the UN General Assembly in 1997. While the former was specific to European countries when it was first adopted, it has since opened to any country that accedes to the treaty anywhere in the world. Other conventions address specific components of transboundary basins, such as the Convention on Wetlands of International 
Importance, which provided a framework for national action and international cooperation for the conservation and wise use of wetlands and their resources, which was signed in 1971.

Institutions such as global international treaties, joint technical committees, or River Basin Organizations (RBOs) are more localized mechanisms used by governments from national to local scales to monitor, provision, or otherwise organize water resources use, access, and protection. Treaties help states organize their interactions over shared water resources and minimize conflicts over resources and communicate their goals, needs, and values in the negotiation process [1]. Agreements can vary in spatial scale through differences in the total area of interest to address a shared water resource, or the continuity of the territory covered in the treaty based on the number of riparian states participating in the agreement [2]. Assessments of the impacts of international agreements over transboundary water resources management have identified the utility of treaties in increasing cooperative behavior even when water availability is uncertain or variable, and across political power disparities among treaty signatories $[1,3]$. Such assessments follow the approach to examining the role of institutions like agreements in water management and conflict transformation began with the Basins at Risk (BAR) project of the Transboundary Freshwater Dispute Database (TFDD) out of Oregon State University [4].

Also within the TFDD is a register of international RBOs based on the significant legal and organizational characteristics of these institutions identified by Schmeier and colleagues [5,6]. RBOs are institutions with broad mandates in which representatives of riparian countries manage shared surface water resources. Past scholarship used the presence of both a treaty and an RBO in a river basin as an indicator of cooperative intent between countries $[7,8]$. RBOs can be effective institutions for managing international water resources through both politically challenging and environmentally complex management problems [9]. As Wolf, Stahl, and Macomber (2003) initially noted, these institutions themselves do not necessarily have the capacity to meet either their own stated goals or to address the challenges that water management entails [10]; prohibitive challenges include water scarcity, inequities in the distribution of the water resource, pollution from exogenic sources relative to the basin, and legal limitations in the organizations' power [11,12]. The structure of these organizations is traditionally considered the most important determinant of this degree of effectiveness $[8,10]$.

\subsection{The Spiritual and Intrinsic Dimensions of Water}

Institutions such as international conventions, agreements, and RBOs reflect the policy priorities and management choices favored by the participating stakeholders. The development of these priorities into shared policies implies a complementary set of favored dimensions of water or values associated with water needs, which may differ between signatories. In the practice of facilitating international freshwater resource management discussions, focusing on common values rather than stakeholder-differentiated needs or issues tends to result in more cooperative discussion processes and holistic treaties. This work also examines how the process of transboundary water management negotiations occur in a four-level process, which correlate with four worlds, or dimensions, of water: the physical, emotional, mental, and spiritual. Using a value-centered dialogue, with the aim of moving towards a fourth and final dialogue level of the universality and spirituality of water, management negotiations can avoid tendencies of thinking for short-term needs, and can help promote conversations in water management that last in the long-term [13].

The considered, or overlooked, values associated with the intrinsic, spiritual, sustainable, and culturally-aware dimensions of water are distinct across the scales of international institutions used to organize their interactions over shared water resources. Intrinsic valuing of water resources manifests from a recognition of the importance of a water resource for its own existence, rather than for a tangible environmental good, service, or benefit derived from it. This recognition could take the form of environmental preservation measures, or protection of endemic organisms or ecosystems, or some similar policy [14]. Spiritual and 
culturally-linked local value-recognitions of water would recognize the connections formed between the human spirit, soul, or collective group to a water resource, as opposed to material or physical things that come from a water resource. This could include awareness of aspects of water which foster a connection between the measurable, physical aspects of the world, and the harder to measure social, emotional, and cultural norms of place or group. In short, the spiritual aspects of water would focus on connections and relationships with some form of 'other' - other people and their needs, the water resource itself, or something else [13]. This paper uses a multi-scalar on international institutions to identify areas of disconnect in the values expressed in different interactions and organizations over shared water resources. We consider variations in value-expressions across communityspecific intrinsic and spiritual dimensions of water, regional management institutions or international agreements, and global conventions. The scale-based structure of the article highlights the systems-based connections, and disconnections, from global to local-scopes of dimensions of water enshrined in different institutions. This systematic-perspective is particularly relevant when the global environment includes actors from outside of riparian areas with possible levers of influence through funding and global political standing.

\section{Materials and Methods}

\subsection{Data Sources}

This study is based on documentary evidence from the TFDD regarding the expression of values associated with different dimensions of water in international water management institutions' documents and policies. The International Freshwater Treaties Database (IFTD) is a subset of the TFDD hosted by Oregon State University, initially described by Hamner \& Wolf (1997) and re-assessed by Giordano, et al., (2013) [15,16]. The IFTD catalogues international agreements pertaining to shared freshwaters treated as consumable resources and describes them along content characteristics such as topic area, document type, whether or not uncertainties of water availability or needs are addressed, and compliance monitoring $[15,17]$. This database was the source for documents describing institutions and principles expressed within the global community and more regional international agreements.

The International River Basin Organizations Database (IRBOD) is another aspect of the TFDD, which organizes established RBOs according to legal, organizational, and topical characteristics based on work by Schmeier $[5,9,17,18]$. The IRBOD provided information on the common characteristics and sourcing documents for RBOs assessed in this paper regarding evidence of the inclusion of different dimensions of water in more local management institutions and scales. With international RBOs identified through the ITFD and IRBOD, further document collection included evidence about the RBOs mentioned from relevant RBO websites, if they are available, including reports on programs funded by RBOs in each transboundary river basin and website content for these RBOs. In her work developing a system to codify RBOs by their legal characteristics, Schmeier and colleagues used a similar approach of combining primary and secondary information about these organizations $[5,8]$. The assessment presented in this paper examining values and dimensions of water followed a document- and media-based snowball sampling technique in collecting these resources, which included documents sourced on the RBOs to look for additional references based on publications cited within those documents.

\subsection{Assessing Dimensions of Water}

Characteristics of global conventions, international agreements, and international RBOs already included in the codebooks of the IFTD were used to identify documents from institutions which contain value expressions associated with the intrinsic or spiritual dimensions of water (Table 1; [17]). The IFTD includes international treaties from any part of the world dated from 1820-2017, which defines the period of documentary information and analysis. The number of value-expressions in documents based on the IFTD codebook served as a 'net' to gather the established IFTD documents that express values related to 
the intrinsic or spiritual dimensions, themes, and approaches to sharing water resources (Table 1). This step set an initial, broad assessment of the degree of value-signaling within scale of international institutions and the countries who participate in those institutions. The values-net contains five categories of selected values and expresses as the number of value categories contained in a treaty; values-net scores range from 0 (no values in the net contained in a treaty) to 5 (all five value categories of the net found in the treaty). The score does not indicate the number of times a value was expressed within a document, or the incorporation or importance of the value to the content; these concerns are considered in a second-round of document-specific cases coded with the guiding methods in Table 2. Net scores apply to documents based on their unique identification numbers rather than lineage, a previous distinction when analyzing documents from in this database [16].

Table 1. Values-net attributes associated with dimensions of water value-expressions coding components based on the International Freshwater Treaties Database codebook. These components were selected based on their capacity to capture views of water related to the intrinsic or spiritual values of water based on a holistic, cross-cultural, and environmentally and socially integrated approach to water management.

\begin{tabular}{|c|c|c|c|}
\hline $\begin{array}{l}\text { Codebook } \\
\text { Attribute }\end{array}$ & Code & IFTD Meaning * & Code Justification \\
\hline Issue Area & $\begin{array}{l}\text { Joint Management } \\
\text { OR: Water Quality } \\
\text { OR: Water Quantity }\end{array}$ & $\begin{array}{l}\text { 'Joint Management': the portion of } \\
\text { the document discussing water } \\
\text { resources involves joint } \\
\text { management between signatories. } \\
\text { 'Water Quality': includes } \\
\text { water-related environmental } \\
\text { concerns to water quality. } \\
\text { 'Water Quantity': addresses concerns } \\
\text { about amounts of water mentioned. }\end{array}$ & $\begin{array}{l}\text { Spiritual: Joint management of a water resource beyond } \\
\text { socio-political boundaries common in response to managing } \\
\text { water resources for common concerns about water supply } \\
\text { and expressing concerns for caring for those who need } \\
\text { water in scarcity contexts-emphasizes cross-boundary care } \\
\text { and concern, inter-community connection;Intrinsic: Concern } \\
\text { for the environment into parity with a holistic concern for } \\
\text { the balance of human-nature relationships through quantity } \\
\text { and quality concerns }\end{array}$ \\
\hline Environment & $\begin{array}{l}\text { Environmental services: An } \\
\text { agreement that explicitly } \\
\text { mentions environmental } \\
\text { services or Protection }\end{array}$ & $\begin{array}{l}\text { Treaty explicitly mentions } \\
\text { environmental services or } \\
\text { protection }\end{array}$ & $\begin{array}{l}\text { Intrinsic: Concern for the environment into parity with a } \\
\text { holistic concern for the balance of human-nature } \\
\text { relationships, such as protection of water resources }\end{array}$ \\
\hline $\begin{array}{l}\text { Equity or } \\
\text { Sustainability }\end{array}$ & $\mathrm{Y}$ & $\begin{array}{l}\text { An agreement in which parties refer } \\
\text { to some general principle, such as } \\
\text { equity, sustainability, rationale etc., } \\
\text { which should overarch their } \\
\text { cooperative endeavors }\end{array}$ & $\begin{array}{l}\text { Spiritual/Intrinsic: Guiding rationales such as equity or } \\
\text { sustainability imply connections across communities and } \\
\text { generations for water access (spiritual) and preservation } \\
\text { of resources for human and non-human use or recovery } \\
\text { of ecosystems (intrinsic) }\end{array}$ \\
\hline Local Needs & $\mathrm{Y}$ & $\begin{array}{l}\text { An agreement which explicitly } \\
\text { states that the needs of the local } \\
\text { population living in border areas } \\
\text { should be considered. }\end{array}$ & $\begin{array}{l}\text { Spiritual/intrinsic: local needs in balance with capacities } \\
\text { of natural resources, such as water supply }\end{array}$ \\
\hline People's Interests & $\mathrm{Y}$ & $\begin{array}{l}\text { The treaty indicates that it was } \\
\text { signed or designed for the interests } \\
\text { of a specific population, or that the } \\
\text { concerns of a population were taken } \\
\text { into consideration or addressed in } \\
\text { the document. }\end{array}$ & $\begin{array}{l}\text { Used in conjunction with Local Needs in a Boolean OR } \\
\text { function. See notes in 'Local Needs'. }\end{array}$ \\
\hline $\begin{array}{l}\text { Joint } \\
\text { Management }\end{array}$ & $\mathrm{Y}$ & $\begin{array}{l}\text { An agreement which institutes some } \\
\text { form of joint management } \\
\text { institution or Commission -a } \\
\text { specialized institutional body for } \\
\text { issues stipulated in the treaty and } \\
\text { whose scope of action and authority } \\
\text { depends upon the treaty. The } \\
\text { mandate may be more narrowly } \\
\text { defined than a River Basin } \\
\text { Organization. }\end{array}$ & $\begin{array}{l}\text { Spiritual: Joint management of a water resource beyond } \\
\text { socio-political boundaries common in response to } \\
\text { managing water resources for common concerns about } \\
\text { water supply and expressing concerns for caring for } \\
\text { those who need water in scarcity contexts }\end{array}$ \\
\hline $\mathrm{RBO}$ & $\mathrm{Y}$ & $\begin{array}{l}\text { The document establishes a River } \\
\text { Basin Organization for the joint } \\
\text { management of shared water } \\
\text { resources under a broad or general } \\
\text { mandate that encompasses issues } \\
\text { across an entire basin. }\end{array}$ & $\begin{array}{l}\text { Used in conjunction with Joint Management (below) in a } \\
\text { Boolean OR function. See notes in 'Joint Management' } \\
\text { Label. }\end{array}$ \\
\hline
\end{tabular}


Table 2. Qualitative spiritual and intrinsic dimensions of water evaluation codes developed from an inductive review of seminal spiritual ecology literature. These codes further hone the understandings and values of water within assessed documents beyond the initial selection criteria of codes from the IFTD established codebook.

\begin{tabular}{|c|c|c|}
\hline Code & Description & Values \\
\hline $\begin{array}{l}\text { Future } \\
\text { Generations/Long-term } \\
\text { planning }\end{array}$ & $\begin{array}{c}\text { Does the document mention concern for } \\
\text { "future generations," or otherwise concern } \\
\text { about long-term needs for water planning and } \\
\text { access? }\end{array}$ & $\begin{array}{c}-1 \text { = document specifically notes that future } \\
\text { uses cannot proscribe current uses of water in } \\
\text { context of the document } \\
0=\text { not mentioned } \\
\begin{array}{c}1=\text { long-term planning mentioned, no explicit } \\
\text { use of "future generations" } \\
2=\text { "future generations" mentioned }\end{array}\end{array}$ \\
\hline $\begin{array}{l}\text { Food Security (primarily } \\
\text { regarding irrigation and } \\
\text { fishing) }\end{array}$ & $\begin{array}{c}\text { Are food security concerns related to } \\
\text { irrigation/agriculture or fishing mentioned } \\
\text { substantively? }\end{array}$ & $\begin{array}{c}0=\text { not mentioned } \\
1=\text { mentioned, but only briefly } \\
2=\text { mentioned as a central issue in the } \\
\text { context/goal of development } \\
3=\text { irrigation/aquaculture overdevelopment } \\
\text { mentioned as a concerning threat to water } \\
\text { quality, as an area that needs } \\
\text { improvement/advancement, etc }\end{array}$ \\
\hline Rare Ecosystem & $\begin{array}{l}\text { Does the document include concern for an area } \\
\text { for its ecological or biological status? }\end{array}$ & $\begin{array}{c}0=\text { not mentioned } / \text { not applicable } \\
1=\text { mentioned tangentially, briefly, as a } \\
\text { sub-concern of the treaty } \\
2=\text { mentioned as an early or central issue; a } \\
\text { guiding concern of the document }\end{array}$ \\
\hline $\begin{array}{l}\text { Protection of } \\
\text { waterquality/quantity }\end{array}$ & $\begin{array}{c}\text { Does the treaty state concern for water quality } \\
\text { issues? (Inclusive of allocation amounts, } \\
\text { preventing pollution, concern for protecting } \\
\text { water quality) }\end{array}$ & $\begin{array}{c}0=\text { not mentioned, not applicable } \\
\begin{array}{c}1=\text { brief mention of concern for water quality, } \\
\text { flow rates, discharge, other technical } \\
\text { regulations }\end{array} \\
2=\text { water quality/quantity is a central issue the } \\
\text { treaty, or guiding concern }\end{array}$ \\
\hline Other Earth Respect & $\begin{array}{l}\text { Does the treaty express some other concern for } \\
\text { respecting an ecological, biological, or other } \\
\text { environmental attribute worthy of protection? }\end{array}$ & $\begin{array}{l}\text { Yes } \\
\text { No }\end{array}$ \\
\hline $\begin{array}{l}\text { Outside Basin Reference/ } \\
\text { Pressure }\end{array}$ & $\begin{array}{l}\text { Does the document mention a global/regional } \\
\text { agreement or group (ex., UN program, World } \\
\text { Bank donors, etc.) as a driving cause of } \\
\text { wanting to generate this document? }\end{array}$ & $\begin{array}{l}\text { Yes } \\
\text { No }\end{array}$ \\
\hline Culture/water reference & $\begin{array}{l}\text { Does the document recognize cultural/social } \\
\text { importance of referent water resources? }\end{array}$ & $\begin{array}{l}\qquad 0=\text { not mentioned } \\
1=\text { Statement that is either overbroad about } \\
\text { environmental protection and cultural ties, or } \\
\text { overly specific to a particular sectoral resource } \\
\text { harvesting practice that is only briefly } \\
\text { mentioned without context provided. Includes } \\
\text { if cultural concerns about environment in } \\
\text { general mentioned, within a broader water } \\
\text { context, that these might be put at risk about a } \\
\text { specific activity, etc. } \\
2=\text { water cultural importance specifically } \\
\text { mentioned as an area of concern and needing } \\
\text { protection }\end{array}$ \\
\hline Keywords & $\begin{array}{l}\text { Keywords from document indicating central } \\
\text { values or principles }\end{array}$ & $\begin{array}{l}\text { Phrases collected inductively from } \\
\text { documents/sources }\end{array}$ \\
\hline
\end{tabular}

Based on the value expressions from the broad net described in Table 1, documents from all institution types-global conventions, international agreements, and RBOs-also were coded based on a qualitative, inductively-developed series of values-codes. This 
secondary content-analysis applied to international agreements with at least three netdetected values and recorded the presence or absence of additional values inductively developed (Table 2). Agreements representing notable instances of country-signatures, unique by either the time or geographic clustering of the country-signatures, were also purposefully included in this secondary qualitative sampling step.

In extension to the global convention and international agreement selection criteria described above, RBOs were similarly selected for a limited comparative case study analysis. This step assessed RBOs possibly signaling their concern or management choices based on intrinsic or spiritual dimensions or values of water. The comparative case analysis section developed an understanding of RBOs as institutions in which states can follow through on previously expressed management goals and values contained in treaties. Selected RBOs were those which manage transboundary river basins covered by a treaty with at least two net-detected value-signals other than the Joint Management/RBO value. This selection method ensured that the RBOs in this analysis existed under some previous context of intrinsic or spiritual dimension value-signaling by member states, thus indicating that these RBOs potentially function as forums in which states acted, or did not act, on previously-stated values of water. This was not selecting on the dependent variable; rather, this limiting criteria for $\mathrm{RBO}$ case studies set parameters to assess if previously expressed values in international institutions are pushed aside when states engaged in drawn-out management necessities, even when they also had indicated that they supported certain values.

This study relies on iterative inductive learning across new fields of scholarship and a variety of international and agency-specific documents and reports. An inductive approach provided the nuance for understanding the different meanings and contexts in which values were supported by states, and for an adaptive process to detect differences as they arise. The complexity of values associated with water and their application across different scales and political interactions recommended this inductive-based approach to testing the foundational connections between disciplines and complex aspects of water management that inform the dual coding and organization processes in this study.

\subsection{Scale-Based Approach}

Within the use of the value-net and IFTD, the analysis focused on the unit of "countrysignatures". These country-signatures represented the number of times a country signed a treaty with a specific number of expressed values associated with the intrinsic or spiritual dimensions of water. Hence, one treaty with a specific values score could represent two or more country-signature values, depending on if the treaty was bilateral or multilateral. The TFDD was recently updated to along the timeline of the completion of this analysis; the number of treaties and associated country-signatures should represent most treaty documents and involved countries for the assessed database period. The country-signature construct was an organizational unit of analysis; it summarized the occurrences of the broad unit of analysis, value-signals. Geographic and temporal summaries of countrylevel engagement with international freshwater management institutions are established conventions in assessments of treaty or organizational documents from sources such the TFDD [16]. The geographic and temporal summaries assessed the potential for the waxing or waning of specific values over time or specific regions. Understanding if there are rising or waning value-occurrences across time and space informs time and region-based expressions for these values in international freshwater institutions, and possibly indicate areas where recommendations to further enhance the consideration of spiritual and intrinsic dimensions of water would be best received.

The presence of values associated with the spiritual and intrinsic dimensions of water based on the above-described analysis fall across three presented scales: global, regional-international, and localized international management. These scales organize the presentation of the results below, according to their respective international institution: global conventions, international agreements, and RBOs. 


\section{Results}

\subsection{Overall}

The IFTD contains 767 treaties and global conventions between countries over shared freshwater resources dated between 1820-2017. 2242 country-signatures occurred over these 767 documents. About two-thirds of treaties, and three-quarters of country-signatures, supported at least one spiritual and intrinsic dimensions net-detected value. Despite the nearly two-century period of this sample of treaties and country-signatures, the greatest number of country-signatures to treaties with at least one included value in each differentiated score group occurred in the late 20th or 21st century (Table 3). Additionally, the USA had the highest country-signatures to treaties with $0,1,3$, and 4 values per treaty signed, and the total occurrences of country-signatures overall.

Table 3. Summary of overall and score-specific occurrence of dimensions net scores of country-signatures by decade and country 1820-2017. Higher scores indicate greater value-signals relevant for a holistic perspective on water management per country-signature; country-signatures with more value-signals increased in frequency over time, although single-value documents have the most numerous country-signatures.

\begin{tabular}{cccccccc}
\hline & \multicolumn{2}{c}{ Net-Detected Values Included per Treaty Signed } & Total \\
\hline Country-signatures & 0 & 1 & 2 & 3 & 4 & 5 & All Scores \\
\hline Score Count $\left(\mathrm{x}_{\text {score }}\right)$ & 595 & 634 & 351 & 279 & 257 & 126 & 2242 \\
\hline Score $\%$ of $\mathrm{N}$ & $27 \%$ & $28 \%$ & $16 \%$ & $12 \%$ & $11 \%$ & $6 \%$ & - \\
\hline Score $\%$ of $\mathrm{n}$ & - & $38 \%$ & $21 \%$ & $17 \%$ & $16 \%$ & $8 \%$ & - \\
\hline Modal Decade & $1950-1959$ & $1960-1969$ & $1990-1999$ & $1990-1999$ & $2000-2009$ & $2000-2009$ & $1990-1999$ \\
\hline Modal Country & USA & France & USA & USA & Russia & Tanzania & USA \\
\hline
\end{tabular}

Of the RBOs selected for the comparative case study of more local institutions, only eight were accessible with enough information to provide for full analysis (Table 4; Appendix A). Several international agreements established RBOs between countries that are no longer in operation, which was particularly common in the La Plata River Basin and in several basins in Africa. These organizations were not further analyzed in this study due to a focus on operational approaches of current RBOs (Figure 1). 
Table 4. RBOs and foundational agreements organized by transboundary river basin of operation considered for assessment based on current operational status and accessible information.

\begin{tabular}{|c|c|c|c|c|}
\hline Basin & RBO Name & Foundational Agreement & Year & Member Countries \\
\hline Congo/Zaire & $\begin{array}{l}\text { Lake Tanganyika } \\
\text { Authority }\end{array}$ & $\begin{array}{l}\text { The Convention on the Sustainable Management of } \\
\text { Lake Tanganyika }\end{array}$ & 2003 & $\begin{array}{l}\text { Burundi, Tanzania, } \\
\text { Congo DR (Kinshasa), } \\
\text { Zambia }\end{array}$ \\
\hline Nile & $\begin{array}{l}\text { Lake Victoria Basin } \\
\text { Commission }\end{array}$ & $\begin{array}{l}\text { Protocol for Sustainable Development of Lake } \\
\text { Victoria Basin. Arusha, } 29 \text { November } 2003\end{array}$ & 2003 & Kenya, Tanzania, Uganda \\
\hline Orange & $\begin{array}{l}\text { Orange-Senqu River } \\
\text { Commission }\end{array}$ & $\begin{array}{l}\text { Agreement Between the Governments of the Republic } \\
\text { of Botswana the Kingdom of Lesotho the Republic of } \\
\text { Namibia and the Republic of South Africa on the } \\
\text { Establishment of the Orange-Senqu Commission }\end{array}$ & 2000 & $\begin{array}{l}\text { Botswana, Lesotho, } \\
\text { Namibia, South Africa }\end{array}$ \\
\hline Volta & Volta Basin Authority & $\begin{array}{l}\text { Convention on the status of the Volta River and the } \\
\text { Establishment of Volta Basin Authority }\end{array}$ & 2007 & $\begin{array}{c}\text { Benin, Burkina Faso, } \\
\text { Ivory Coast, Ghana, Mali, } \\
\text { Togo }\end{array}$ \\
\hline Zambezi & $\begin{array}{l}\text { Zambezi Watercourse } \\
\text { Commission }\end{array}$ & $\begin{array}{l}\text { Agreement on the Establishment of the Zambezi } \\
\text { Watercourse Commission }\end{array}$ & 2004 & $\begin{array}{l}\text { Angola, Botswana, } \\
\text { Mozambique, Malawi, } \\
\text { Namibia, Tanzania, } \\
\text { Zambia, Zimbabwe }\end{array}$ \\
\hline Oder & $\begin{array}{l}\text { International } \\
\text { Commission for the } \\
\text { Protection of the Oder } \\
\text { against Pollution }\end{array}$ & $\begin{array}{c}\text { Convention on the International Commission for the } \\
\text { Protection of the Oder }\end{array}$ & 1996 & $\begin{array}{l}\text { Czech Republic, } \\
\text { Germany, Poland }\end{array}$ \\
\hline Torne & $\begin{array}{l}\text { Finnish-Swedish } \\
\text { Transboundary River } \\
\text { Commission }\end{array}$ & $\begin{array}{l}\text { Agreement between Finland and Sweden concerning } \\
\text { transboundary rivers }\end{array}$ & 2009 & Finland, Sweden \\
\hline La Plata & $\begin{array}{l}\text { Trinational Commission } \\
\text { for the Development of } \\
\text { the Pilcomayo River Basin }\end{array}$ & $\begin{array}{l}\text { Agreement constituting the trilateral commission for } \\
\text { the development of the Pilcomayo river basin }\end{array}$ & 1995 & $\begin{array}{l}\text { Argentina, Paraguay, } \\
\text { Bolivia }\end{array}$ \\
\hline
\end{tabular}

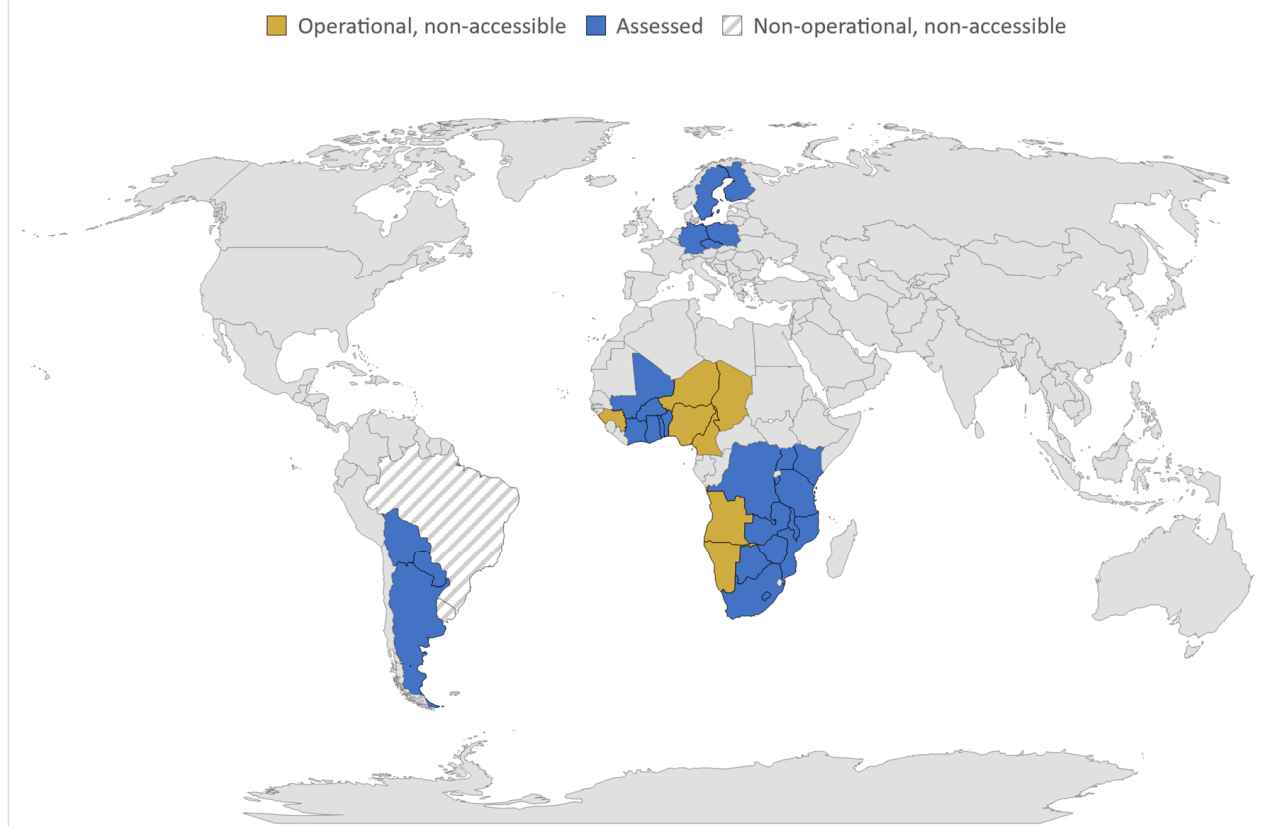

Figure 1. Distribution of member-countries to RBOs assessed as case studies in this paper, or of historical or inaccessible RBOs otherwise meeting the selection criteria as potential case studies. Several RBOs in Africa are operational but not accessible due to language or online-security barriers, whereas most qualifying organizations in South America are no longer operating despite a half-century history of La Plata Basin countries establishing joint institutions together. 


\subsection{Global Scale: Global Conventions}

Documents that guide ethics at the global scale, by their nature, need to be quite general. As such, the potential for disconnect with local values is exceedingly high, and has resulted in occasional setbacks. For example, one of the 1992 Dublin Principles suggested that, "water has an economic value in all its competing uses and should be recognized as an economic good". This contrasted with some interpretations of Islam that suggests that water is a gift from God, and can thus never be bought and sold. In fact, resistance in global fora was quite strong, and the current set of principles, as adopted by the Global Water Partnership, was modified to read, "Water is a public good and has a social and economic value in all its competing uses." (https:/ / www.gwp.org/contentassets/05190d 0c938f47d1b254d6606ec6bb04/dublin-rio-principles.pdf) (28 June 2021).

Subsequent documents of global principles likewise only allude to local values, and rarely explicitly. The 1992 UNECE Convention, for example, focuses on water quality, and generally in quite technical terms. The only two real exceptions are that impacts may include, "effects on the cultural heritage," and sustainability is defined as meeting the needs of the present generation, "without compromising the ability of future generations to meet their own needs." (https://unece.org/DAM/env/water/pdf/watercon.pdf) (Accessed date: 28 June 2021). The 1997 UN Convention has broader scope, including all non-navigational uses of transboundary waters, but is likewise quite technical, albeit recognizing "social and economic needs," as potential uses.

\subsection{International Regional Scale: International Agreements}

Inclusions of values associated with the spiritual or intrinsic dimensions of water built slowly over the last two centuries. The first two decades of documents contained no value-signals assessed for in the value-net, with no treaties from the 1830s recorded in the IFTD overall (Figure 2). The first treaty containing spiritual ecology-related values was in 1848 (The "Treaty of peace, friendship, limits, and settlement between the United States of America and the United Mexican States concluded at Guadalupe Hidalgo, 2 February 1848 " addresses local needs for water access in border communities of the Rio Grande and Colorado River basins.). All country-signatures in this decade apply to documents that primarily focused on border delimitation based on water bodies, and through the 1950s European and then North American countries contributed the greatest number of countrysignatures to value-inclusive treaties during the 1950s, most of which were single-value documents. These treaties mostly contained one net-detected value (Figures 2 and 3). The most common values driving this score were the Issue Area or Joint Management/RBO code within the net, both of which mostly focused on an infrastructure or hydropower projects, rather than a true focus on the dimensions of water the net was supposed to detect. As a tool for detecting treaty-cases for examining the presence of spiritual or intrinsic aspects of water-related values in these documents, the values net thus presented as an initially over-broad tool for early-period documents in the TFDD (Appendix B). 


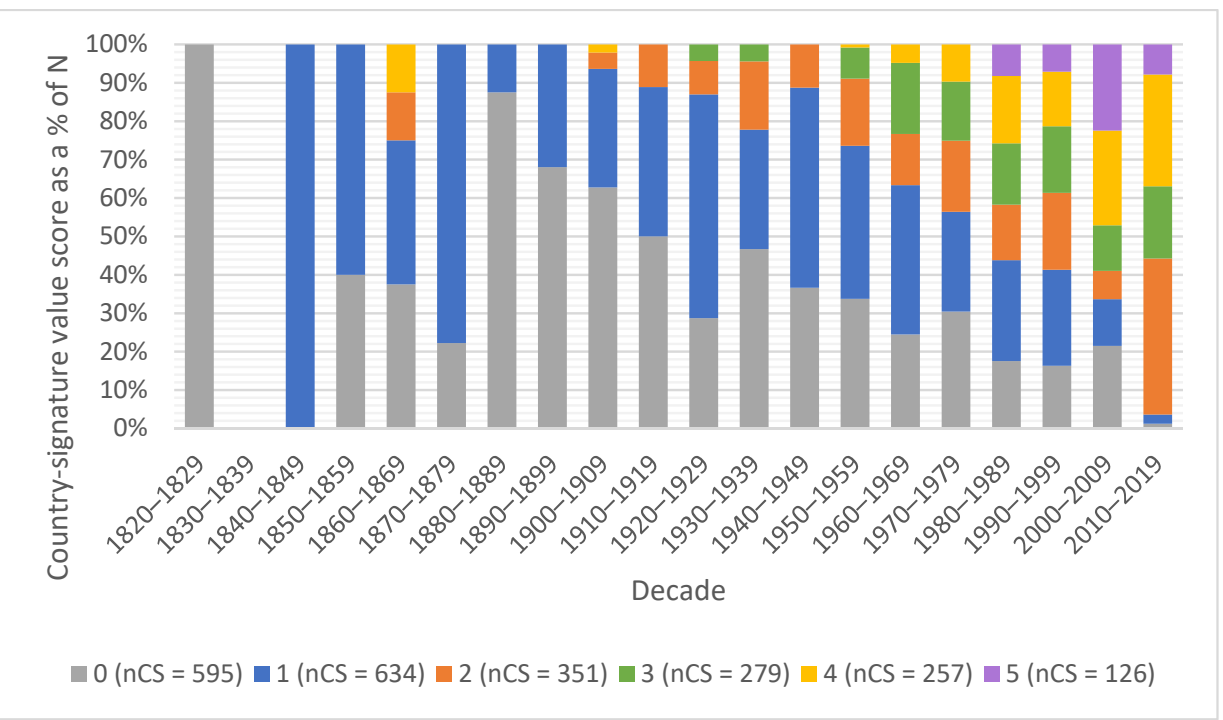

Figure 2. Decade-summarized count of country-signatures of all treaties based on the number of values $(0,1,2,3,4$, or 5) expressed by a country-signature to an international agreement. Over time, countries sign smaller proportions of treaties with no spiritual ecology-related value signals per decade, and a greater proportion of country-signatures support documents with more values included.

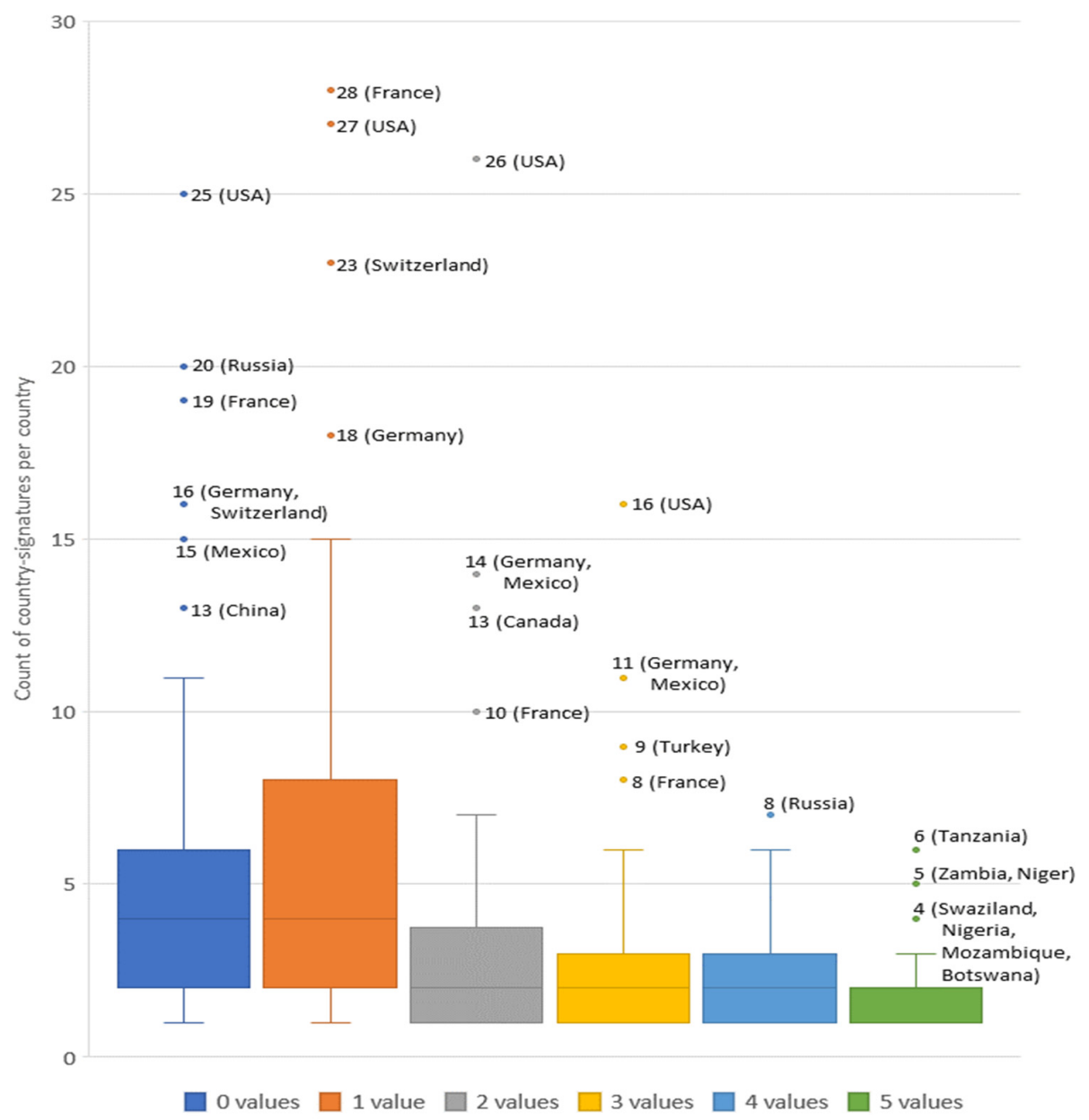

Figure 3. Box-and-whisker plot of country-signatures per country with differentiated net-detected values. Wealthy, northern countries tend to dominate in signing high numbers of treaties with only one or no values, whereas there is more regional and power-based diversity among the signatories of high-scoring treaties. 
The momentum of country-signatures transitioning from single-value treaties compounded into rising percent shares of the country-signatures on treaties with more than one value and multiple value-inclusions per agreement (Figure 2). The 1980s began a slight shift in more evenly distributed country-signatures to treaties with multiple net detected-values (Figure 2). Particularly regarding treaties with very high value- occurrences in this period, Western European countries led this transition with a focus on monitoring industrial sector impacts on water resources (For example: Convention between the government of the French Republic and the government of the Grand Duchy of Luxembourg for the realization and exploitation of certain industrial settlements on the Moselle, signed 12 March 1986).

Momentum built over time for the secondarily-coded values at this scale as well. Treaties in the latter two decades also contained the strongest, most consistent inclusion of the inductively-assessed dimensions-based codes. Most of the documents contained concern for intergenerational water justice, specific measures to monitor or prevent pollution locally, and an expression of concern for a specific local ecosystem or non-human needs for water. This time-based evidence indicated increasing support values associated with the spiritual and intrinsic dimensions of water, and that policies seek to address these issues; additionally, the effectiveness of the values-net in accurately reflecting water-related spiritual ecology value signals in treaties appeared to increase over time.

Generally, northern-latitude or wealthier regions-such as Europe or the oil-rich Gulf-tend to have only a small number of isolated countries with a notably higher modal commitment to treaties with more net-detected values, and these regional leaders are surrounded by mostly low-modal commitment countries. Finland, Ireland, and Georgia in Europe, and Turkey and Saudi Arabia and Jordan in the Middle East, represent this pattern. In contrast, southern latitudes and regions with predominantly small or mid-sized economies tend to have regional clustering of high scores between countries, creating contiguous multi-national regions of greater value occurrences (Figure 4).

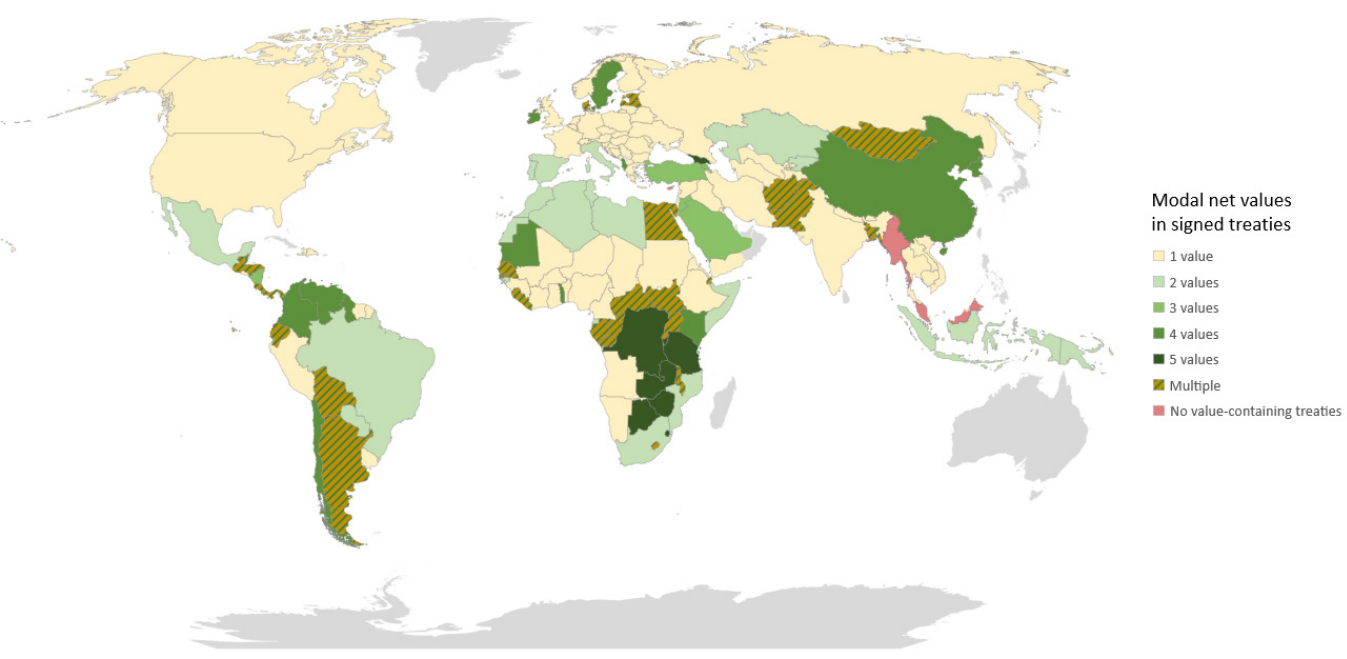

Figure 4. Geographic distribution of the modal value scores of countries for their most-often supported number of netdetected values per country-signature based on the sample of treaties containing at least one net-detected value (n). Northern or wealthier regions tend to show isolated regional leaders with notably higher modal scores, whereas southern areas show regional clustering of high-intensity support for net-detected values among groups of neighboring countries.

The content and context of these scores and the documents they relate to create another geographically-differentiated factor in the expression of values associated with the spiritual and intrinsic dimensions of water. Many countries in North and South America signed at least one treaty with all net-detected values, while very few countries in Asia (The only example of this is the Agreement on Joint Activities in Addressing the Aral Sea and the Zone around the Sea Crisis, improving the Environment, and Ensuring the 
Social and Economic Development of the Aral Sea Region, signed 26th March 1993 by Kazakhstan, Kyrgyzstan, Tajikistan, Turkmenistan, Uzbek-istan in Central Asia) or small areas of Europe (In addition to the aforementioned Protocol on the Protection of the Marine Environment of the Black Sea from 2009 signed by Georgia and Bulgaria, France and Luxembourg signed a Convention on 12th March 1986 to jointly develop the Moselle River in the Rhine basin for industrial use. Later, the 12th April 1999, Convention on the Protection of the Rhine was signed by Germany, France, Luxembourg, The Netherlands, Switzerland, and European Community) signed treaties with all five values in the net. However, most of the European and North American high-value agreements approach their shared water resources differently from the Central Asian, South American, and African agreements. European and North American agreements, while high-scoring, focus on small sub-basin areas or on specific sectoral-based activities associated with those areas. In contrast, agreements connecting African and South American countries speak more generally about sustainable development and equitable resource access alongside environmental protection or conservation.

\subsection{Regional-Local Management Scale: River Basin Organizations Comparative Case Studies}

One of the goals in assessing the RBO cases and their expressed and operationalized values was to compare with those values expressed in the RBO foundational treaties. The inductively developed codes for water values and goals are grouped for presentation and discussion from most oriented for anthropocentric needs and for specific sectors (i.e., irrigation or fishing) to broader, more integrated codes incorporating both eco-centric and anthropocentric concerns which relate to the spiritual and intrinsic dimensions of waterrelated values. Additionally, the outside basin reference code served a separate function as a category detecting potential interceding influences from non-riparian or non-local entities, as described below (Table 5).

In both treaties and RBOs, the food security code was one of the rarest. Only the LTA expressed the rare ecosystem code, despite the relative frequency of this value among the original agreements. This occurred in the context of the LTA describing Lake Tanganyika as a distinctly valuable ecosystem and region (Table 5; Appendix C). Linking culture \& water between treaties and $\mathrm{RBO}$ s was similarly rare; only one $\mathrm{RBO}$ mentioned it in its foundation document, ZWC, and then acted on it. The other two RBOs that were based on treaties that incorporated this value, ORASECOM and Comisión/Pilcomayo, did not operationalize it. However, this value did manifest in RBO activities without the foundation agreement expressing interested in the concept in the LTA and LVBC. Overall, culture \& water was only meaningfully operationalized in RBOs in Africa, and only in three of the five RBOs on that continent in this study. The FSTRC in Europe expressed this value in its foundational documentation and provided information on the Fishing Rule that was the basis of the FSTRC's focus on this value (Appendix C).

Both protection of water quality \& quantity and outside basin reference were mentioned in every RBO case, even when foundational agreements did not identify these elements initially. Most of the water protection activities addressed immediate pollution concerns and preventing future contamination, however both European RBOs either only addressed flooding prevention, or prioritized it above other concerns, unlike the other cases. When quantity concerns were mentioned, these included flooding in specific contexts (ICPO, Comisión/Pilcomayo, ZAMCOM); the ABV was the only African RBO that did not explicitly address flows in the context of environmental needs (Appendix $C$ ).

The comparison code, outside basin references, was similarly consistent in all RBO cases, although fewer foundational treaties substantially referenced a potential outside influencer or reference that could affect the values operationalized in a specific context. Only treaties from African river basins mentioned non-riparian entities, normally the South African Development Community, United Nations, or World Bank. However, every RBO emphasized the presence of these or additional outside entities. The RBO that expressed the fewest occurrences or least reliance on non-riparian entities was the Comisión/Pilcomayo, 
which only began referencing a funder in 2017, after being in operation since 1995 . The ICPO had the most central relationship to an outside reference, as it was formed explicitly to implement the European Union Water Directive Framework; however, this was not mentioned in its foundational agreement from 1996. Referring to a broad number of outside international entities as funders of specific programs and interests for all the organizations in Africa, although the LTA and ZAMCOM were particularly specific in listing these organizations and the impact of these institutions on their own programming (Appendix $\mathrm{C}$ ).

Table 5. Values manifestations in RBO case studies in comparison to values expressed in foundational treaties [T]. Cells colored in blue indicate that the RBO case study included the value in its operations, regardless of the presence or absence of the value in the organization's foundational document, indicated by the marker [T]. White cells indicate that the RBO case study did not indicate the listed value. All RBO cases but the LTA and FSTRC had notable patterns of mis-match between the values in their foundational documents, and the values implemented in their operations.

\begin{tabular}{|c|c|c|c|c|c|c|c|}
\hline & $\begin{array}{c}\text { Food } \\
\text { Security }\end{array}$ & $\begin{array}{c}\text { Protection } \\
\text { of Water } \\
\text { Qual/Quant }\end{array}$ & $\begin{array}{c}\text { Rare } \\
\text { Ecosystem }\end{array}$ & $\begin{array}{c}\text { Other } \\
\text { Earth } \\
\text { Respect }\end{array}$ & $\begin{array}{l}\text { Culture \& } \\
\text { Water }\end{array}$ & $\begin{array}{l}\text { Future } \\
\text { Genera- } \\
\text { tions }\end{array}$ & $\begin{array}{l}\text { Outside } \\
\text { Basin } \\
\text { Reference }\end{array}$ \\
\hline $\begin{array}{l}\text { Congo/Zaire: Lake } \\
\text { Tanganyika Authority }\end{array}$ & $\mathrm{T}: 2$ & $\mathrm{~T}: 2$ & $\mathrm{~T}: 1$ & $\mathrm{~T}: \mathrm{Y}$ & & $\mathrm{T}: 2$ & $\mathrm{~T}: \mathrm{Y}$ \\
\hline $\begin{array}{l}\text { Nile: Lake Victoria Basin } \\
\text { Commission }\end{array}$ & $\mathrm{T}: 2$ & $\mathrm{~T}: 2$ & $\mathrm{~T}: 2$ & T:Y & & $\mathrm{T}: 2$ & \\
\hline $\begin{array}{l}\text { Orange-Senqu: } \\
\text { Orange-Senqu } \\
\text { Commission }\end{array}$ & & $\mathrm{T}: 2$ & $\mathrm{~T}: 1$ & $\mathrm{~T}: \mathrm{Y}$ & $\mathrm{T}: 1$ & $\mathrm{~T}: 1$ & $\mathrm{~T}: \mathrm{Y}$ \\
\hline $\begin{array}{c}\text { Volta: Autorite du Bassin } \\
\text { de la Volta }\end{array}$ & & & $\mathrm{T}: 1$ & & & & $\mathrm{~T}: \mathrm{Y}$ \\
\hline $\begin{array}{c}\text { Zambezi: Zambezi } \\
\text { Watercourse Commission }\end{array}$ & & $\mathrm{T}: 2$ & & & $\mathrm{~T}: 1$ & $\mathrm{~T}: 2$ & $\mathrm{~T} ; \mathrm{Y}$ \\
\hline $\begin{array}{l}\text { Oder/Odra: International } \\
\text { Commission for the } \\
\text { Protection of the Odra } \\
\text { River against Pollution }\end{array}$ & & $\mathrm{T}: 2$ & $\mathrm{~T}: 2$ & & & & \\
\hline $\begin{array}{l}\text { Torne: Finnish-Swedish } \\
\text { Transboundary River } \\
\text { Commission }\end{array}$ & $\mathrm{T}: 2$ & $\mathrm{~T}: 1$ & & & $\mathrm{~T}: 1$ & & $\mathrm{~T}: \mathrm{Y}$ \\
\hline $\begin{array}{l}\text { La Plata: Trinational } \\
\text { Commission for the } \\
\text { Development of the } \\
\text { Pilcomayo River Basin }\end{array}$ & $\mathrm{T}: 1$ & $\mathrm{~T}: 1$ & $\mathrm{~T}: 1$ & & $\mathrm{~T}: 1$ & & \\
\hline
\end{tabular}

Note: " $\mathrm{T}$ " in a value-box indicates that this value was signaled in the foundational treaty document for an $\mathrm{RBO}$, and the numerical or $\mathrm{Y} / \mathrm{N}$ code indicates the content in the treaty according to the inductive coding process for the treaties.

\section{Discussion}

\subsection{Global Conventions}

The concept that the worlds of rationality and spirituality are separate and distinct is a relatively recent phenomenon historically, common only within very specific geographic locales in the world, a product of 18th Century Western Europe. What we now call the "Enlightenment," in temporal terms, suggested that day-to-day considerations should be gauged only in measurable, "objective" concepts, while the world's spiritual dimension should be considered separately, in the evening at home or within one's Friday, Saturday, or Sunday community (See Martin (2007) for a good summary of the evolution of the Enlightenment). For much of the rest of the world outside of Europe and North America, though, especially amongst religious, local, and/or indigenous communities, the worlds of rationality and spirituality continue to be considered as one unified whole, perpetually intertwined and ideally in balance (think of the Taijitu, the traditional Taoist symbol for yin and yang, for example), and we separate them at our peril.

In the water world, we similarly tend to separate the rational and spiritual components both of the resources and of the process of resolving disputes. In dialogues in the 
industrialized West, most or all focus is on the rational—physical water, i.e. the water we see, touch, move; or "mental" water-consideration of its efficiency or price, for example. In contrast, many spiritual and indigenous consideration supplement these two "waters" with two others: "emotional" water, those aspects of water that are connected to history, sovereignty, power, and justice; and spiritual water, where just about every community of faith in the world incorporates water in its conception of spiritual transformation.

As noted above, the global principles might mention non-technical or non-economic values in passing, but are generally extremely disconnected from the local and indigenous ethics as expressed within these communities. As we drop in scale, some "Western" nations have increasingly been reaching out to their indigenous communities for the language to describe these concepts. The New Zealand National Water Policy was developed in 2014 with close participation of the Maori community, resulting in explicit language referring to the spirituality of water:

"All things in the natural world have mauri (life force) and wairua (a spiritual dimension). Respect for the spiritual integrity of the environment and the atua (God) that created it will ensure that the taonga (treasure) can be protected and passed on to succeeding generations."

\subsection{International Agreements: Interest Building over Time and through Regional Leaders}

At smaller scales away from international conventions, states support or engage with spiritual, long-term, intrinsic and culturally-grounded values in water management differently depending on the scale facilitating management discussions. Values associated with the spiritual and intrinsic dimensions of water proliferated among international agreements only beginning in the 1950s in large numbers. These value-signals were partially a function of the increase in the number of treaties signed during the post-war period per year, and a previously recognized shift of focus of treaties to water quality and environmental concerns [16]. However, this time-focused assessment of the interest in these values needs further research. Previous studies have addressed the role of institutions such as these agreements on shared freshwater resources through building institutions, and trust in institutions even in contentious contexts [19]. But, using institutions in international water management as lenses into the scales of value-interests and value-operationalization choices of states represents a relatively new approach to institution-level research. Previous iterations examining treaties focused on the utility of these documents in water conflict prevention, prediction or mitigation (e.x., 3, 1, 19), and work on developing assessments of RBOs led by Schmeier focused on their role in water diplomacy, rather than program alignment with foundational values $[5,8,20]$.

Regional leadership is another angle to pursue in both further research on the growing potential of spiritual and intrinsic dimensions inclusion in international water management, and work in diverse forms of power and international environmental politics. Ireland, Turkey, Jordan, and other countries previously identified represent a unique geographical pattern of middle-powered countries in their respective regions attaining higher valuecommitments to these alternative dimensions of water from mainstream concerns on water's anthropocentric utilities for industry or agriculture, as examples. While none of these countries are considered particularly powerful overall, Turkey is a localized hydrohegemon in the Tigris-Euphrates river basin with a history or accessing diverse power levers in its international water management interactions with other riparians [21,22]; Jordan has similarly sought alternative bargaining methods in the Jordan River Basin relative to water access negotiations [21,23,24]. Georgia and Ireland, additional high-scoring middling powers in a traditional sense and smaller economies, provide further nuance to the pattern of these types of states taking a value-leadership stance in their immediate regions. Value-leadership could represent a form of power-building in water resource discussions, either through setting key ideational aspects of discussions or attracting the attention of outside actors in support of their efforts through compliance with global governance values of sustainable development and institution-building. 
This pattern persisted in southern latitudes, again setting evidence for a pattern of states expressing these values in the context of their political and environmental needs. The most visible example of this pattern is in southern Africa, wherein seven countries' modal value-commitments were to treaties with five net-detected values (Figures 3 and 4). Neighboring countries with multiple modal scores also reported, among their multiple modes, higher-value modes, including Uganda, the Central African Republic, Gabon, Congo, and South Sudan. Mongolia and Pakistan both have high multi-modal scores, and these countries border China, forming a small regional cluster. Finally, in South America, northern Andes and Amazon-basin countries cluster together with consistent 4 value modal treaty signatures; their multi-modal neighbors include immediate neighbors as well as a generally large contiguous area of countries from Mexico to Brazil and Chile which generally support treaties with at least two spiritual or intrinsic dimension-related values in most country-signatures (Figure 4). These are also considered less-developed economies which will be limited in their ability to achieve their goals in water management discussions through political or economic capacities. Including values in high concentrations of the treaties they sign could represent attempts to signal to other actors with greater capacities regarding their interest in implementing regional approaches to cooperation, long-term water management, and ecosystem protection [1]. These organizations could include global entities, countries with interests in foreign aid, and regional groups such as the Southern African Development Community. These countries thus present another important utility of treaties and the assessment of their signaled values, regarding their interest in organizing their relationship goals over shared water resources, even if these countries lack the material capacity to act on them independently.

These country-signatures also applied to treaties which contained more nuanced, context-based expressions of values associated with the spiritual and intrinsic dimensions of water beyond the net's initial indication. For all 3 or 4-valued documents supported by these countries, the missing index value was a concern for local needs of people near a transboundary water resource. Other values, including concerns for environmental or ecosystem water needs, conservation, and water quality in addition to water quantity equity, were present in some respect in all the secondarily-assessed documents. Considering all top-scoring documents were relatively recent agreements, this pattern connects a previous observation made by Giordano et al. that explicitly concerns and protections of water quality for ecosystem or environmental needs were increasingly prominent aspects of the documents in the IFTD, possibly as an effect of major international environmental policy developments like the UN Rio de Janero summit in 1992 [16].

However, keywords and guiding principles in these documents varied by region. European and North American documents contained more limited scopes in terms of additional spiritual and intrinsic dimensions of water-related values. Documents from African and South American countries and transboundary river basins included these values, but they were secondary to concerns about equity in resource utilization, sustainable development, and were where most expressions of concern for specific ecosystems or biodiversity occurred in the documents. The expressions of both anthropocentric and ecosystem-inclusive nature of these documents indicated the occurrence two possible trends. The dualities of the expressed values could indicate an interceding impact of these countries seeking external support for their goals regarding the management of their water resources-all documents from African countries with these high scores reference a regional or global program focused on environmental protection or sustainable development in some way. The simultaneous expressions of development concerns alongside local-scale environmental protection interests could also represent an exemplary demonstration of how spiritual and intrinsic dimensions of water-facilitated values towards the management of resources like water do not necessarily manifest as anti-development aspirations, which offsets a potential critique of policies based on these dimensions of water. 


\subsection{River Basin Organizations and Local-Regional Management Leadership}

With the profiles in treaty and RBO expressions of these interconnected values, two potential patterns are plausible when extending this concept to how water values related to spiritual and intrinsic dimensions of water are affirmed in political and management contexts (Figure 5). One interpretation is that when countries enter negotiation rooms to work on treaty contents, those values that fall more on the interconnection-based interpretation of human-environmental relationships are harder for states to express or commit to publicly; however, these connections then become realities for the RBOs they establish and the on-the-ground work that is carried out by these organizations. Thus, treaties may not express values focused on human-environmental hydrological connections, but these connections become unavoidable and manifest when managers must implement projects. The alternate, or potentially co-occurring, pattern recognizes the difference between treaty negotiation processes and $\mathrm{RBO}$ activities. $\mathrm{RBOs}$ have a much greater need for funds to support ongoing, often highly-technical and expensive, programs [25]. In contrast, treaty negotiations can be more short-term affairs in terms of the time 'in-the-room' by ministers and country representatives. This greater need for funds during implementation and management may create more room for outside entities with previously expressed interests and values to insert themselves into the management practices of RBOs, while treaty negotiations may occur with less of this interference or influence.

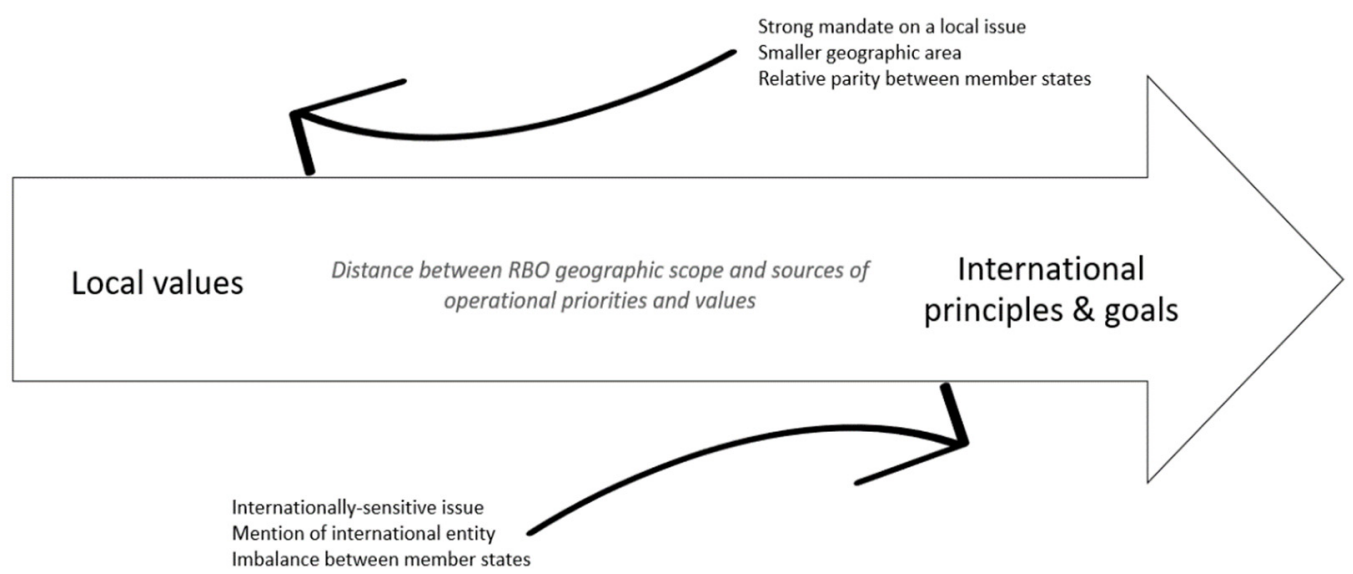

Figure 5. Conceptual outline of factors pushing closer, more local values or farther, international values, into the primary operation of RBOs at local water management institutional scales.

International nongovernmental organizations, funding institutions, and other regional and global entities have set several standards for what these organizations view as appropriate water management principles and priorities. These include UN documents, the International Law Association, the World Bank, and grant-making entities within the European Union like the Nordic Development Fund and the German government, among others [26]. Additionally, nongovernmental organizations such as the United Nations or organizations focused specifically on water management such as the Global Water Partnership, which can provide funding to poorer regions for projects aligning with their own goals, can add or suppress values that states may otherwise support or bypass without the presence of these organizations. The presence or reference to these organizations was common across both treaties and RBOs, although less prevalent in political interactions over smaller water resources, in wealthier regions, or in less well-known water bodies. These entities do influence RBO structures and organizational scopes in this region, although without consideration of the priorities and values expressed in those operations [25]. International conventions can establish some of these principles that are imposed on more regional organizations $[27,28]$.

The work of this study did not directly focus enough on the potential sources and patterns of international pressure and references on more local scales of behavior, instead 
representing a beginning path to cataloging the differences of water values across those scales. Thus, the abovementioned two potential interpretations cannot be fully answered and explored in this work. However, there are some initial, guiding patterns present in these RBO cases that can guide further work in this area, which will be informative given approaching goal-dates for international programs like the Sustainable Development Goals for 2030. International entities may be exerting influence to encourage the presence of State commitments to values associated with both sector-specific and human-ecological interconnected values. Whether or not these values would have manifested in these areas, mostly in Africa, is unknown; however, in RBOs in similar contexts as described without numerous references to outside references or funders in Europe and South America, such values were entirely absent or not operationalized.

\subsection{Intrinsic and Spiritual Dimensions of Water across Institutions Management Scales}

Value-signaling and engagement with values associated with sustainable, culturallyaware and intrinsic and spiritual dimensions of water are distinct between scales of water managing-institutions. Working to understand how values reflecting long-term sustainability management priorities manifest in international political interactions begins with focusing on important institutions. When examining these institutions as mediums for value-expressions, they generate different behavior profiles regarding dimensions of water considered in each institution. States express in treaties generalized values regarding environmental protection and sustainability, or the physical needs of their constituent populations in relation to water supply and quality. RBOs emphasize these concerns, in programs that are sector-specific or focused on the water and food security of local communities. However, RBOs are forums that more frequently recognize the cultural impacts of water management decisions on local communities. Local or epistemic communities can be important influencers in international discussions on sustainability and resource management, particularly on the value of water associated with its cultural or spiritual connotations [29], although only RBOs directly mention the role of these communities. Local scales of management and actors can thus be a source of ground-up leadership on the voicing and incorporation of these concerns into scaled-up international institutions.

The least common value-expression overall, and hardest to capture in treaties despite RBO-level engagement on the topic, was explicit linkages between culture and water. While several RBOs indicated that these inherently culturally-grounded environmental concerns for water were considered in their programming and planning, treaties contained both less intensive and less frequent mentions of these concerns. Altogether, the values inductivelydeveloped from spiritual ecology literature and refined in the treaties and RBO documents manifested within the four worlds structure outlined in work conceptualizing the four worlds of water $[13,14]$. With the preceding patterns in mind, treaties and RBOs also behave differently when looking through the prism of the four worlds along two distinct value-expression profiles (Figure 6). Treaties move upwards and decline in frequency and intensity from the physical to spiritual worlds of how water policies manifest as values. RBOs maintain a robust physical base alongside the treaties that founded them; however, in implementation they hollow-out in comparison to a more intensive and frequent commitment to the most culturally-integrated value within water management, linkages between culture and water. 


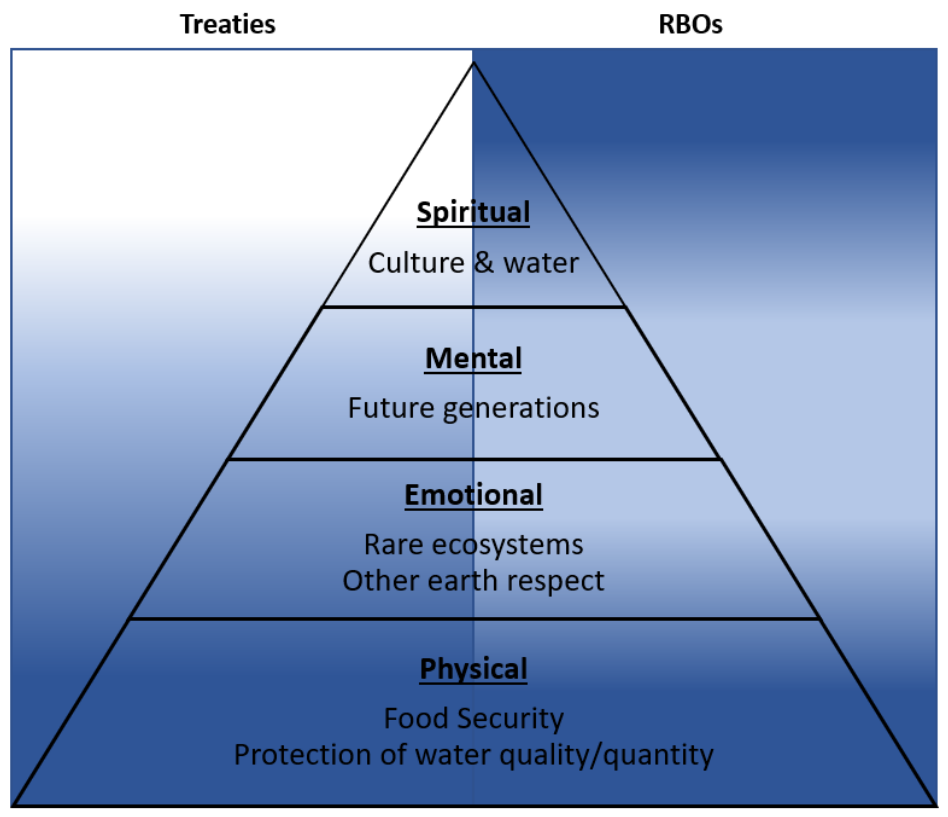

Figure 6. Differing treaty and RBO manifestations of the four worlds of water. Darker colors indicate higher occurrence of those values in the interaction arena, organized by 'four worlds of water' category. International agreements and RBO cases show different patterns of the values of water that they express unique to these arena types.

\section{Conclusions}

Water management decisions within political interactions are ultimately based on the values that actors hold when interacting with each other. Detecting when values that inform more sustainable, long-term, and culturally-integrated approaches to water based on its intrinsically-held or spiritually-based importance can identify opportunities to expand the activities by states associated with these values. This assessment highlights that signals of values in international water management institutions related to the intrinsic and spiritual, or environmental protectionism and inter-community connectivity and recognition, vary across the scale of institutions, time of establishment, and place. Currently, such values are growing in frequency and intensity of support in international agreements signed by states. However, global conventions and RBOs-the institutional scales addressing larger and smaller scopes than international regional treaties-express a greater variety of these values at a greater proportion than regional treaties. A more informed understanding of the values of implementing organizations such as RBOs can help the rising variety of states interested in these values implement programs in a more targeted, effective manner appropriate to their goals, location and interests.

Author Contributions: Conceptualization, E.L.P. and A.T.W.; methodology, E.L.P.; software, E.L.P.; validation, E.L.P.; formal analysis, E.L.P.; investigation, E.L.P. and A.T.W.; resources, E.L.P. and A.T.W.; data curation, E.L.P.; writing — original draft preparation, E.L.P.; writing—review and editing, E.L.P. and A.T.W.; visualization, E.L.P.; supervision, A.T.W.; project administration, A.T.W.; funding acquisition, A.T.W. All authors have read and agreed to the published version of the manuscript.

Funding: This research received no external funding.

Institutional Review Board Statement: Not applicable.

Informed Consent Statement: Not applicable.

Data Availability Statement: Data informing this work can be found in the Transboundary Freshwater Dispute Database (2018) [17].

Conflicts of Interest: The authors declare no conflict of interest. 


\section{Appendix A}

Table A1. Example documents and language from IFTD agreements highlighting content from treaties that was either accurately included within a specific net value theme, or inaccurately included due to the net being overbroad and initially designed from the IFTD codebook. Most inaccurately included values were from the early period (1820-2017) in the IFTD documents.

\begin{tabular}{c}
\hline Net-Included Value \\
\hline Issue Area (summary code \\
described the general content of an \\
international agreement relevant to \\
its freshwater-focused content. As \\
such, it will not have specific text or \\
clauses of an agreement to refer to in \\
a justification in most cases.): Joint \\
Management, Water Quality, Water \\
Quantity
\end{tabular}

Inaccurately included: Treaty between Austria and Bavaria concerning the regime of the frontier line and other territorial relations between Bohemia and Bavaria (1862)
Accurately included: The Convention on the Sustainable Management of Lake Tanganyika (2003)
Example International Freshwater Treaty

Language Examples or Justification

"The objective of the present convention is to ensure the protection and conservation of the biological diversity and the sustainable use of the natural resources of Lake Tanganyika and its Basin by the Contracting States on the basis of integrated and co-operative management" - the document goes on to establish the Lake Tanganyika Authority's legal permissions and organizational structure.

The document protects the ability of individual irrigators to continue to draw from "existing conduits or water courses out of frontier brooks" following a change in borders between signatories; the document is brief, and addresses no other topics. No mention of interests or goals for water use are given other than for private irrigation, which itself also is not the central focus of the document.

Accurately included: Joint declaration of principles for utilization of the waters of the lower Mekong Basin, signed by the representatives of the governments of Cambodia, Laos, Thailand, and Vietnam to the Committee for Coordination of Investigations of the Lower Mekong Basin (1975)

"When developing its Basin water resources, each Basin State shall take such measures as are practicable and reasonably necessary to avoid or minimize detrimental effects upon the ecological balance of the Basin, or any part thereof"

Inaccurately included:

NA — of all documents assessed directly, all coding of Environment: 2 were accurate.

Equity/Sustainability: Y

Accurately included: Protocol for Sustainable Development of Lake Victoria Basin (2003)

"managed in an integrated and holistic manner," "sustainable development," "equitable and reasonable utilization"

"rational exploitation of the resources of the

Inaccurately included: Convention Relating to the Statute of the Senegal River (1964) basin"-Exploitation is too single-system, anthropocentric, and economic-uses focused to be an accurate value expression for the value-net system.

Accurately included: The Convention on the Sustainable Management of Lake Tanganyika (2003) "...accord particular attention to ensuring that present and future communities living near the Lake benefit from the sustainable use of the Lake's natural resources and amenities"

"Seeing that the international line follows in various parts the course of the waters and the direction of the roads, and touches at some springs, it is agreed that the waters, roads, and springs in such cases shall be jointly used by the people of both kingdoms"-The text is about the general accessibility of bridges over water, not the needs of local communities regarding water resource.

Portugal and Spain (1864)

Accurately included: Agreement of cooperation between the government of the Eastern Republic of Joint Management OR RBO: Y Uruguay and the Federal Republic of Brazil for the use of natural resources and the development of the basin of the Cuareim River (1991)

Inaccurately included: A treaty regarding navigation and hydraulic works along the rivers Vistula and San [no title available] (1871)
"Uruguay-Brazilian Joint Commission for the Development of the Rio Cuareim Basin" based on the standards set by the Joint Commission for the Development of the Lake Merin Basin

The Joint Management aspect of this document relates to the planning of infrastructure projects through Commissioners for navigation pathways, which is not an expression of water as a consumable resource to meet the needs shared between signatories. 


\section{Appendix B. RBO Case Descriptions and Cited Evidence}

\section{Appendix B.1. Congo/Zaire: Lake Tanganyika Authority (LTA)}

The Lake Tanganyika Authority (LTA) was the only RBO that pre-dated its foundational document for the values-assessment in this work. The 2003 Convention provided a directive from member countries to restructure the organization and focus on new goals (Lake Tanganyika Biodiversity Project Regional Steering Committee, 2000). Part of the restructuring integrated economic-sector representatives into working groups and committees (Lake Tanganyika Authority, 2011). There were several consistent themes in organization from before and after the 2003 shift. One economic sector of particular emphasis was fisheries management as a concern of this region. Consistently in technical reports about the basin and the LTA's work, local communities and traditional practices are partially blamed for Lake Tanganyika degradation, although livelihoods, traditional practices, and cultural heritage concerns and protections are also raised in organizational planning documents (Lake Tanganyika Biodiversity Project Regional Steering Committee, 2000). Often within the same document, the LTA expresses concerns for cultural human activities in the basin alongside clear statements about specific human activities, particularly farming, clear cutting and logging, and fisheries, among poor communities, as threats to the health of the basin (Lake Tanganyika Biodiversity Project Regional Steering Committee, 2000; Nkotagu et al., 2000). The LTA also identified implementation of projects as a pillar of this organization; however, the authority to implement is in the hands of the participating countries, not the LTA itself. Countries have unique assignments of projects to implement, many of which overlap but are inherently considered national-level programs with similar themes (Lake Tanganyika Biodiversity Project Regional Steering Committee, 2000).

\section{Appendix B.2. Nile: Lake Victoria Basin Commission (LVBC)}

While the foundational document for this RBO only had participation from Uganda, Tanzania, and Kenya, two additional states entered the LVBC through its sponsorship with the East African Development Community: Rwanda and Burundi (Who We Are, 2016). Generally, there were very few resources and documents to work with from this organization, even though everything was available in English. This is an organization with an interest in managing all the natural resources of the basin, not just water resources; however, there are several water-specific projects for pollution management that lend water resources special attention by LVBC. These have also been particularly active programs with on-the-ground, community-scale, tangible results to report (LVEMP II, 2016; LVWATSAN II, 2016). Additionally, the LVBC has a core program that directly links environmental and human health, with consideration to how the environmental influences local livelihoods (PHE, 2016). However, there is a paired set of programs focused on a unique theme among the cases in this study, meant to encourage and manage private sector investment in the Lake Victoria area. The programs seek to target private sector involvement in "green growth," particularly in relation to large-scale agriculture; there is also a grievancereporting program associated with this initiative to provide local communities with a pathway to communicate to private entities if problems from infrastructure programs arise (Engaging Private Sector for Green Growth in Lake Victoria Basin (EPSGG-LVB) Project, 2016; EPSGG-LVB Project Grievance Redress Mechanism (GRM), 2016).

\section{Appendix B.3. Orange-Senequ: Orange-Senequ Commission (ORASECOM)}

ORASECOM members include all riparian states in the basin: Botswana, Lesotho, Namibia, and South Africa. It is guided along six themes for action and use of its resources: Institutional and Organizational Strengthening; Specific Capacity Building on Shared Watercourses Management; Development of Shared Information Systems; Enhancing ORASECOM Communication and Awareness Building; Specific Transboundary Projects and Studies; Promotion of Conservation and Environmental Strategies and Policies (Programmes, 2020). In the context of these goals, water is generally seen as an economic resource to be managed for anthropocentric, extractive purposes and economic activities 
(Pegram \& Baleta, 2014). This general view of water resources does contain recognition of environmental protection and conservation concerns. ORASECOM also is one of the few cases of surface water-focused organizations with a unique, specific program to help meet irrigation needs; however, there is no mention of the issue in the foundational 2000 Agreement. Both early documents from this organization and more recent continuing projects emphasize limiting the actions of the RBO and shifting focus to functions related to sharing information about water resources rather than implementing or recommending management programs. Additionally, this organization places a high emphasis on ensuring the participating states have their sovereignty recognized and not impeded (Dickens, 2009).

\section{Appendix B.4. Volta: Autorite du Bassin de la Volta}

The first convention founding the Autorite du Bassin de la Volta (ABV) was signed in 2007 by Mali, Ghana, Togo, Benin, Burkina Faso, and Cote d'Ivoire. This is the youngest organization in this study. The original intent of the organization was to facilitate collaborative development of the basin's water resources, particularly through integrated water resources management-based approaches and manage joint projects and programs, generally with the goal of poverty reduction (Historical, 2020). In 2018, the RBO led the drafting of a new Water Charter for the Volta River Basin. This document was meant to revitalize the organization and mandated the creation of several programs including those for managing shared aquifers, protecting biodiversity, and climate change adaptation. Member states are considered the primary stakeholders, however non-State entities are also are to be integrated into decision-making and planning efforts, including traditional and cultural local leaders specifically (Draft Water Charter for the Volta River Basin, 2018). However, the organization does not have an active history of implementing projects before the 2018 draft charter. In general, this organization provided little information on itself or on its programs. From what information was provided, only programs related to further institutional planning, and helping states assess management options and decision-making processes, were reported on, and met, by the self-imposed deadline of December 2019.

\section{Appendix B.5. Zambezi: Zambezi Watercourse Commission (ZAMCOM)}

Angola, Botswana, Malawi, Mozambique, Namibia, Tanzania, Zambia, and Zimbabwe in the Zambezi basin first negotiated an agreement establishing ZAMCOM came into agreement in 2004, but only into force in 2011 due to delays in riparian ratification of the agreement. This basin has the highest number of participating states of all cases. The original intent of the organization was to provide assistance to states as the primary actors of water management policies (ZAMCOM History, 2020). Since this earlier intent, the strategic plan and implemented projects expanded this original function. The organization has a specialized focus on flood and drought preparedness, in addition to providing data on water resources in the basin directly and without end-user cost on their website. The organization focuses on the use and extraction of economic value from water resources. However, in balance with this focus is a common, guiding concern and awareness of planning for the needs of future generations; the land, the water and the resources derived from these, are culturally perceived as "held and used in trust" on behalf of future generations (Zambezi Watercourse Commission, 2019; Zambezi Watercourse Commission et al., 2015).

\section{Appendix B.6. Oder-Odra: International Commission on the Protection of the Oder (ICPO)}

Unlike every other RBO in this sample, one of the original signatories to the Convention establishing the International Commission on the Protection of the Oder against Pollution (ICPO) in 1999 was the European Community as a regional entity, in addition to Poland, Germany, and the Czech Republic. The European Community left the organization after 2005 when Poland and the Czech Republic became independent states within the European Union. The organization focuses on freshwater resources from the Oder, and with marine protection of the Baltic Sea (Information about ICPO, 2020). Beyond basic information about the basin there was minimal primary English resources from this organi- 
zation, and these were mostly for tourist use (Krakowski, 2012; Tourist Guide Map, 2015). This organization is also unique in that its purpose was not to fulfill aims set out in its foundational document directly; instead, it was creased to implement the Water Directive Framework of the EU and reach its goals by 2015 (General Information: International Commission for the Protection of the Odra River, 2013). To achieve these ends, ICPO implements its own programs and recommendations; however, the basin is divided into either sub-units each of which are self-contained national or sub-national units, and none are transboundary. Within these units, countries are responsible for program implementation and local issues, in addition to the work established by the regional ICPO.

\section{Appendix B.7. Torne: Finnish-Swedish Transboundary River Commission (FSTRC)}

Finland and Sweden each has three representatives who comprise the Finnish-Swedish Transboundary River Commission, which was established in 2009 relevant to border rivers and a small area of the Baltic Sea near the Arctic Circle boundary (Finnish-Swedish Transbound. River Comm., 2021; Members, 2021). The FSTRC holds to the issues established in its foundational document, the Agreement between Finland and Sweden Concerning Transboundary Rivers, flood monitoring and fishing management. The website only provides information published from other sources, such as its foundational agreement and conventions or directives from other organizations, such at the European Union Water Framework Directive or the United Nations Law of the Sea. However, unlike any other case in this study, it provides translations of its 2009 Agreement in two indigenous languages in the area, in addition to Finnish, Swedish, and English. The Commission's activities are limited to public opinions on permitting decisions made by the governments of Finland and Sweden, and taking legal action within the separate legal systems of each country to oppose permitting decisions that impact flood prevention or fishing activities. Otherwise, the Commission can only advise or support cooperation efforts between the separate agencies of each country regarding water management in relation to its two thematic foci.

\section{Appendix B.8. La Plata: Comisión Trinacional para el Desarrollo de la Cuenca del Río Pilcomayo (Comisión/Pilcomayo)}

Argentina, Bolivia and Uruguay signed an agreement establishing the Comisión Trinacional para el Desarrollo de la Cuenca del Río Pilcomayo (Comisión/Pilcomayo) in 1995. This is one of multiple attempts to establish transboundary management in this river basin, but one of the few still operating. The organization was initially operating in three thematic areas: monitoring, planning and management, and sustainability. However, multiple consecutive annual reports noted that the last area, sustainability, was regularly underfunded to the point that no programs could be conducted. Beginning in 2017, the action areas changed to be: monitoring and databases, planning and management, and communication and participation, reflecting a shift in focus of the organization to data collection, reporting, and communication. This information focuses on flooding and pollution concerns, although the organization does develop recommendations for the member states. This shift also came at the time the Comisión first noted its only outside support for its projects, the International Development Bank. Before 2017, no outside funders or references were mentioned; this is entirely unique among the case studies. 


\section{Appendix C}

Table A2. Contexts of value expressions across RBO cases and example language.

\begin{tabular}{ccc}
\hline River RBO (Transboundary & Value Expression & Context of Operationalization \\
River Basin: Member States) & \\
\hline
\end{tabular}

Lake Tanganyika Authority (Congo/Zaire: Burundi, DR Congo, Tanzania, Zambia)
A. Earth respect
B. Protection of water quality
C. Culture/ water reference
D. Rare ecosystem
E. Future generations
F. Outside basin references
G. Food security

A. The LTA general objective as mandated from the foundational 2008 Convention is, "to ensure the protection and conservation of the biological diversity and sustainable use of the natural resources of Lake Tanganyika and its basin" (Lake Tanganyika Authority, 2011)

B. Reducing water pollution in the Lake is a priority operation of the LTA (Lake Tanganyika Authority, 2011); The Polluter Pays principles is a central concept guiding LTA program decision-making; in addition, addressing pollution resulting from human activities and its impacts on the lake is a concern and action area of the LTA (Lake Tanganyika Biodiversity Project Regional Steering Committee, 2000)

C. The LTA recognizes Lake Tanganyika as a cultural heritage site through the 2003 Convention that founded it(Lake Tanganyika Authority, 2011); recognition of the linkages between local livelihoods and the health of the lake is in core planning documents (Lake Tanganyika Biodiversity Project Regional Steering Committee, 2000)

D. Participating countries in the basin view Lake Tanganyika as a "unique environment" globally for history and biodiversity. LTA has a core objective of including biodiversity protection and conservation, in balance with the sustainable use of the basin resources (Lake Tanganyika Biodiversity Project Regional Steering Committee, 2000; Nkotagu et al., 2000)

E. "The four countries share a common desire for the sustainable management of the natural resources and biodiversity of Lake Tanganyika for the benefit of present and future generations"-Principles of environmental management and social development integrated intro strategic outlook (Lake Tanganyika Biodiversity Project Regional Steering Committee, 2000)

F. African Development Bank, Nordic Development Fund, FAO, UNDP, Global Environmental Facility, IUCN, UNEP, and NIGLAS are all cited as supporters of the Regional Integrated Management Programme and its projects (Lake Tanganyika Authority, 2011); additionally, three notable international agreements are directly referenced as documents expressing values that the participating countries want to act on-Convention on Biological Diversity, Agenda 21, and the Dublin Principles (Lake Tanganyika Biodiversity Project Regional Steering Committee, 2000); the Transboundary Diagnostic Analysis project was initially conceived just for biodiversity assessment, however funding support from GEF directly influenced a shift to also including assessment of sustainable management opportunities (Nkotagu et al., 2000)

G. Fisheries and aquaculture concerns associated with water management, including pollution risks and invasive species from these practices as well as their benefits in nutrition and poverty reduction are a thematic focus of the organization (Lake Tanganyika Biodiversity Project Regional Steering Committee, 2000; Tanganyika Lake Map, Facts \& Fish, 2017)
Lake Victoria Basin Commission (Nile: Uganda, Kenya, Burundi, Tanzania, Rwanda)
A. Outside basin reference

B. Protection of water quality

C. Culture/ water reference

D. Future generations
A. Funding institutions like the World Bank, African Development Bank, and USAID are immediately cites in association with specific programs by the LVBC (Who We Are, 2016)

B. Water-specific projects by this organization include pollution prevention and special attention to the effect of urban areas on pollution in Lake Victoria (LVEMP II, 2016; LVWATSAN II, 2016)

C. Environmental health and local livelihood patterns and needs and directly linked in a core program, PHE (PHE, 2016)

D There is a long-term planning aspect, focused on ecosystem stability and sustainable management in the face of climate change (PREPARED, 2016) 
Table A2. Cont.

\begin{tabular}{|c|c|c|c|c|}
\hline $\begin{array}{l}\text { River RBO (Transboundary } \\
\text { River Basin: Member States) }\end{array}$ & & Value Expression & & Context of Operationalization \\
\hline $\begin{array}{c}\text { Orange-Senequ River } \\
\text { Commission (Orange-Senequ: } \\
\text { Botswana, Lesotho, Namibia, } \\
\text { South Africa) }\end{array}$ & $\begin{array}{l}\text { C. } \\
\text { D. }\end{array}$ & $\begin{array}{l}\text { Future generations } \\
\text { Protection of water } \\
\text { quality/quantity } \\
\text { Outside basin references } \\
\text { Food security }\end{array}$ & B. & $\begin{array}{l}\text { A core thematic focus of ORASECOM is climate change } \\
\text { preparedness regarding planning their water resources (Theme } \\
5 \text {-Specific Transboundary Projects And Studies, 2020); future } \\
\text { needs of local communities in groundwater project areas must be } \\
\text { considered in planning water use (Carlsson et al., 2009) } \\
\text { Programs are in place to make sure that lower-basin areas have } \\
\text { assessed and met water flows for environmental health (Theme } \\
5 \text {-Specific Transboundary Projects And Studies, 2020); water } \\
\text { quality monitoring programs also extend to groundwater resources } \\
\text { (ORASECOM, 2009a) } \\
\text { ORASECOM stakeholder engagement planning is justified based } \\
\text { on recommendations and principles established in international } \\
\text { agreements such as the Berlin Rules; additionally, they explicitly } \\
\text { state that they learn from external cases of RBOs best practices from } \\
\text { other transboundary river basins (ORASECOM, 2009b) } \\
\text { Irrigation in the context of groundwater resources, and future } \\
\text { planning for groundwater is based on irrigation needs assessments } \\
\text { (Carlsson et al., 2009) }\end{array}$ \\
\hline
\end{tabular}

Autorite du Bassin de la Volta (Volta: Mali, Ghana, Togo, Benin, Burkina Faso, Cote d'Ivoire)
A. Protection of water quality/quantity
B. Other Earth Respect
C. Outside basin references

A. integrated water resources management is a core implementation goal (Mandate and Objectives, 2020); water quality and quantity management is a revitalized goal of the ABV following the 2018 Draft Charter (Draft Water Charter for the Volta River Basin, 2018)

B. Reforestation and restoration of riverbanks and areas impacted by pollution were early action goals of the Volta Strategic Action Program (VSIP Project, 2020)

C. The re-structured goals of the ABV following the Draft Charter rely heavily on international principles, and international entities are considered stakeholders in decision-making processes for project planning (Draft Water Charter for the Volta River Basin, 2018)
Zambezi Watercourse Commission (Zambezi: Angola, Botswana, Malawi, Mozambique, Namibia, Tanzania, Zambia Zimbabwe)
A. Protection of Water Quality \& Quantity
B. Other Earth Respect
C. Culture \& Water
D. Future Generations
E. Outside Basin Reference

A. Declining water quality, and actions to address water quality issues are actions of focus by the organization (Zambezi Watercourse Commission et al., 2015)

B. Biodiversity protection and protecting forests overall is a central aspect of general environment programs (Zambezi Watercourse Commission et al., 2015)

C. Water is recognized as a cultural resource and as integrated into local traditions; however, ZWC reports also intentionally name traditional and cultural practices as culprits to environmental degradation (Zambezi Watercourse Commission et al., 2015)

D. Water resources and land are seen as held in trust for future generations; sustainable and reasonable use policies for water management are important for protecting the ability of future generations to have access to resources (Zambezi Watercourse Commission et al., 2015)

E. Funders and their specific programs are planned for an incorporated into the plan for the future of the organization (Zambezi Watercourse Commission, 2019)
International Commission on the

Protection of the Oder against

Pollution (Oder-Odra: Poland,

Germany, Czech Republic)
A. Protection of Water

Quality \& Quantity

B. Other Earth Respect

C. Outside Basin Reference
A. Prevention of pollution from entering the Oder and the Baltic Sea is the primary goal of the organization (General Information: International Commission for the Protection of the Odra River, 2013; Information about ICPO, 2020)

B. The organization considers itself as responsible to protect the Oder river for the benefit of "both humans and nature" as an organization applying the Water Framework Directive of the EU (Water Management Plan, 2020)

C. General purpose of the organization is to implement water management goals set by the broad European Union in the Water Framework Direction, rather than specific goals set out by basin riparians (Water Management Plan, 2020) 
Table A2. Cont.

\begin{tabular}{|c|c|c|c|c|}
\hline $\begin{array}{l}\text { River RBO (Transboundary } \\
\text { River Basin: Member States) }\end{array}$ & & Value Expression & & Context of Operationalization \\
\hline $\begin{array}{c}\text { Finnish-Swedish Transboundary } \\
\text { River Commission (Torne: } \\
\text { Finland, Sweden) }\end{array}$ & $\begin{array}{l}\text { A. } \\
\text { B. } \\
\text { C. } \\
\text { D. }\end{array}$ & $\begin{array}{l}\text { Protection of Water } \\
\text { Quality \& Quantity } \\
\text { Food Security } \\
\text { Culture \& Water } \\
\text { Outside Basin Reference }\end{array}$ & $\begin{array}{l}\text { B. } \\
\text { C. } \\
\text { D. }\end{array}$ & $\begin{array}{l}\text { The organization provides information on flood prevention } \\
\text { methods and advising services to the two member governments, } \\
\text { but does not engage in direct programming or monitoring. The } \\
\text { purpose of this advisement is to prevent damages to the } \\
\text { environment and the rivers due to flood events (Flooding Protection, } \\
\text { 2021) } \\
\text { Fishing is the other topical area of interest to the commission, } \\
\text { although it runs no programs independently. It provides public } \\
\text { information on fishing regulations and advises the countries on } \\
\text { how best to cooperate together on the topic (Fishing, 2021) } \\
\text { No direct reference to cultural connections to water are stated; } \\
\text { however, the Commission upholds and provides information on the } \\
\text { Fishing Rule of the Commission, which lists among protected } \\
\text { fishing practices and gear traditional techniques used by } \\
\text { indigenous Sami communities on the River Tornionjonki, including } \\
\text { kulle, lippo, merta, katiska nets and traps. However no explanation } \\
\text { or recognition of this is provided in context (Fishing Rule for the } \\
\text { River Tornionjoki Fishing District, 2021) } \\
\text { The Commission references EU and UN conventions relevant for } \\
\text { freshwater management and coastal areas (Water Management, 2021) }\end{array}$ \\
\hline $\begin{array}{c}\text { Comisión Trinacional para el } \\
\text { Desarrollo de la Cuenca del Río } \\
\text { Pilcomayo (La Plata: Argentina, } \\
\text { Paraguay, Bolivia) }\end{array}$ & $\begin{array}{l}\text { A. } \\
\text { B. }\end{array}$ & $\begin{array}{l}\text { Protection of Water } \\
\text { Quality \& Quantity } \\
\text { Outside Basin Reference }\end{array}$ & A. & $\begin{array}{l}\text { The monitoring development of alert systems against pollution and } \\
\text { flooding was a core action area for annual projects beginning in } \\
2011 \text { (Dirección Ejecutiva de la Comisión Trinacional para el } \\
\text { Desarrollo de la Cuenca del Río Pilcomayo, 2011) } \\
\text { The International Development Bank is the only outside entity } \\
\text { directly referenced regarding programming and financing of the } \\
\text { Comisión (Dirección Ejecutiva de la Comisión Trinacional para el } \\
\text { Desarrollo de la Cuenca del Río, 2019; Dirección Ejecutiva de la } \\
\text { Comisión Trinacional para el Desarrollo de la Cuenca del Río } \\
\text { Pilcomayo, 2020) }\end{array}$ \\
\hline
\end{tabular}

\section{Appendix D. References}

Carlsson, L.; Masalila-Dodo, C.; Benjugam, R.; Sola, L.; Alemaw, B.F.; Mahomed, I.; Madec, G. (2009). Groundwater Review of the Molopo-Nossob Basin for Rurual Communities including Assessment of National Databases at the Sub-Basin Level for Possible Future Integration (Issue 61687).

Dirección Ejecutiva de la Comisión Trinacional para el Desarrollo de la Cuenca del Río. (2019). Informe Anual Técnico: POA 2018. www.pilcomayo.net (26 November 2020).

Dirección Ejecutiva de la Comisión Trinacional para el Desarrollo de la Cuenca del Río Pilcomayo. (2011). Informe Anual Técnico: POA 2011.

Dirección Ejecutiva de la Comisión Trinacional para el Desarrollo de la Cuenca del Río Pilcomayo. (2020). Informe Anual Técnico: POA 2019.

Draft water Charter for the Volta River Basin. (2018).

Fishing. (2021). Finnish-Swedish Transboundary River Commission. https:/ / www.fsgk.s e/Fishing.html (3 March 2021).

Fishing Rule for the River Tornionjoki Fishing District. (2021). Finnish-Swedish Transboundary River Commission. https://www.fsgk.se/Fishing-regulations-.html (3 March 2021).

Flooding Protection. (2021). Finnish-Swedish Transboundary River Commission. https: / / www.fsgk.se/Flooding-Protection.html (3 March 2021).

General information: International Commission for the Protection of the Odra River. (2013). http:/ / www.mkoo.pl/show.php?fid=156\&lang=EN (9 November 2020).

Information about ICPO. (2020). International Commission for the Protection of the Odra River against Pollution. http://www.mkoo.pl/index.php?mid=1\&lang=EN (9 November 2020). 
Lake Tanganyika Authority. (2011). Background/Goals. Website of the Lake Tanganyika Authority.

Lake Tanganyika Biodiversity Project Regional Steering Committee. (2000). The Strategic Action Programme for the Sustainable Management of Lake Tanganyika (Issue July).

LVEMP II. (2016). East African Community: Lake Victoria Basin Commission. https: / / www.lvbcom.org/node/48 (9 November 2020).

LVWATSAN II. (2016). East African Community: Lake Victoria Basin Commission. https:/ / www.lvbcom.org/node/49 (9 November 2020).

Mandate and objectives. (2020). Autorite Du Bassin de La Volta. http://abv.int/en/manda te-and-objectives / (9 November 2020).

Nkotagu, H.; Ledant, J.-P.; Patterson, G.; Allison, E.; Cougny, G.; Henrik, N.I. (2000). Lake Tanganyika: The Transboundary Diagnostic Analysis.

ORASECOM. (2009). A Framework for Monitoring Water Resource Quality in the OrangeSenqu River Basin. http://www.orasecom.org/_system/writable/DMSStorage/661Wate rQualityMonitoringFramework.pdf (12 November 2020).

ORASECOM. (2009). Proposals for Stakeholder Participation in ORASECOM. http:/ / www. orasecom.org/_system/writable/DMSStorage/661ORASECOMStakeholderParticipation Analysis.pdf (12 November 2020).

PHE. (2016). East African Community: Lake Victoria Basin Commission. https:/ /www.lv bcom.org/node/47 (12 November 2020).

PREPARED. (2016). East African Community: Lake Victoria Basin Commission. https: // www.lvbcom.org/node/50 (12 November 2020).

Tanganyika Lake Map, Facts \& Fish. (2017). Lakeopedia. https://www.lakepedia.com/la ke/tanganyika.html (12 November 2020).

Theme 5-Specific Transboundary Projects And Studies, Orange-Senqu River Commission (ORASECOM) (2020). http:/ / www.orasecom.org/programmes/transboundary.aspx (9 August 2021).

VSIP project. (2020). Autorite Du Bassin de La Volta. http:/ / abv.int/en/vsip-project/ (12 November 2020).

Water Management. (2021). Finnish-Swedish Transboundary River Commission. https: / / doi.org/10.18520/cs/v114/i08/1588-1590 (3 March 2021).

Water Management Plan. (2020). International Commission for the Protection of the Odra River against Pollution. https:/ / doi.org/10.9774/gleaf.9781315690261_6 (9 November 2020).

Who We Are. (2016). East African Community: Lake Victoria Basin Commission. https: / / www.lvbcom.org/Whoweare (12 November 2020).

Zambezi Watercourse Commission. (2019). Strategic Plan for the Zambezi Watercourse 2018-2040. www.zambezicommission.org (12 November 2020).

Zambezi Watercourse Commission, Southern African Development Community, \& Southern African Research and Documentation Centre. (2015). Zambezi Environment Outlook 2015.

\section{References}

1. Dinar, S.; Katz, D.; De Stefano, L.; Blankespoor, B. Do treaties matter? Climate change, water variability, and cooperation along transboundary river basins. Political Geogr. 2019, 69, 162-172. [CrossRef]

2. Balsiger, J.; Prys, M. Regional agreements in international environmental politics. Int. Environ. Agreem. Politics Law Econ. 2016, 16, 239-260. [CrossRef]

3. Brochmann, M. Signing River Treaties-Does It Improve River Cooperation? Int. Interact. 2012, 38, 141-163. [CrossRef]

4. Wolf, A.T.; Yoffe, S.B.; Giordano, M. International waters: Identifying basins at risk. Water Policy 2003, 5, 29-60. [CrossRef]

5. Schmeier, S. The Institutional Design of River Basin Organizations-Introducing the RBO Institutional Design Database and Its Main Findings. Int. J. River Basin Manag. 2015, 13, 15-72. [CrossRef]

6. Schmeier, S.; Shubber, Z. Anchoring water diplomacy-The legal nature of international river basin organizations. J. Hydrol. 2018, 567, 114-120. [CrossRef]

7. Milman, A.; Bunclark, L.; Conway, D.; Adger, W.N. Assessment of institutional capacity to adapt to climate change in transboundary river basins. Clim. Chang. 2013, 121, 755-770. [CrossRef] 
8. Schmeier, S.; Gerlak, A.K.; Blumstein, S. Clearing the muddy waters of shared watercourses governance: Conceptualizing international River Basin Organizations. Int. Environ. Agreem. Politics Law Econ. 2016, 16, 597-619. [CrossRef]

9. Schmeier, S. Governing International Watercourses: River Basin Organizations and the Sustainable Governance of Internationally Shared Rivers and Lakes; Taylor and Francis: London, UK, 2012. [CrossRef]

10. Wolf, A.T.; Stahl, K.; Macomber, M.F. Conflict and Cooperation Within International River Basins: The Importance of Institutional Capacity. Water Resour. Update 2003, 125, 31-40.

11. Granit, J. Identifying Business Models for Transboundary River Basin Initiatives. In Transboundary Water Management: Principles and Practice; Taylor and Francis: London, UK, 2013; pp. 143-154.

12. Kliot, N.; Shmueli, D.; Shamir, U. Institutions for management of transboundary water resources: Their nature, characteristics and shortcomings. Water Policy 2001, 3, 229-255. [CrossRef]

13. Wolf, A.T. The Spirit of Dialogue: Lessons from Faith Traditions in Transforming Conflict; Island Press: Washington, DC, USA, 2017.

14. Porta, E.L. Cross-cultural and Sustainability Values in International Freshwater Management Institutions. Master's Thesis, Oregon State University, Corvallis, OR, USA, 12 June 2021.

15. Hamner, J.H.; Wolf, A.T. Patterns in International Water Resource Treaties: The Transboundary Freshwater Dispute Database. Colo. J. Int. Environ. Law Policy 1997, 157, 1-12.

16. Giordano, M.; Drieschova, A.; Duncan, J.A.; Sayama, Y.; Stefano, L.; De Wolf, A.T. A review of the evolution and state of transboundary freshwater treaties. Int. Environ. Politics Law Econ. 2013, 13. [CrossRef]

17. Transboundary Freshwater Dispute Database (TFDD). College of Earth, Ocean, and Atmospheric Sciences, 2018. Oregon State University, 2018. Available online: www.transboundarywaters.orst.edu (accessed on 12 April 2020).

18. Schmeier, S. International RBO Database. Transboundary Freshwater Dispute Database (TFDD). 2017. Oregon State University. Available online: transboundarywaters.science.oregonstate.edu/content/international-river-basin-organization-rbo-database (accessed on 10 September 2020).

19. Odom, O.; Wolf, A.T. Institutional resilience and climate variability in international water treaties: The Jordan River Basin as "proof-of-concept". Hydrol. Sci. J. 2011, 56, 703-710. [CrossRef]

20. Schmeier, S.; Kittikhoun, A. (Eds.) River Basin Organizations in Water Diplomacy; Routledge: Oxfordshire, UK, 2020.

21. Cascão, A.E.; Zeitoun, M. Power, Hegemony, and Critical Hydropolitics. In Transboundary Water Management: Principles and Practice; Taylor and Francis: London, UK, 2010; pp. 27-42.

22. Woodhouse, P.; Muller, M. Water Governance-An historical perspective on current debates. World Dev. 2017, 92, 225-241. [CrossRef]

23. Allan, J.A. Hydro-Peace in the Middle East: Why no Water Wars? A Case Study of the Jordan River Basin. SAIS Rev. 2002, 22, 255-272. [CrossRef]

24. Williams, P.A. Peace Like a River: Institutionalizing Cooperation Over Water Resources in the Jordan River Basin. Colo. Natl. Resour. Energy Environ. Int. Rev. 2017, 28, 313-350.

25. Blumstein, S. Managing Adaptation: International Donors' Influence on International River Basin Organizations in Southern Africa. 2016. Earth System Governance Working Papare No. 36. Lund and Amsterdam: Earth System Governance Project. Available online: www.earthsystemgovernance.org (accessed on 9 August 2021).

26. Wolf, A.T. International Water Convention and Treaties. Encycl. Inland Waters 2009, 1-17. [CrossRef]

27. Conca, K.; Wu, F.; Mei, C. Global regime formation or complex institution building? The principled content of international river agreements. Int. Stud. Q. 2006, 50, 263-285. [CrossRef]

28. Pochat, V. International Agreements, Institutions and Projects in La Plata River Basin. Int. J. Water Resour. Dev. 2011, 27, 497-510. [CrossRef]

29. Witter, R.; Marion Suiseeya, K.R.; Gruby, R.L.; Hitchner, S.; Maclin, E.M.; Bourque, M.; Brosius, J.P. Moments of influence in global environmental governance. Environ. Politics 2015, 24, 894-912. [CrossRef] 